Article

\title{
Demonstration of Allium sativum Extract Inhibitory Effect on Biodeteriogenic Microbial Strain Growth, Biofilm Development, and Enzymatic and Organic Acid Production
}

\author{
Viorica Maria Corbu ${ }^{1,2,3,+} \mathbb{0}$, Irina Gheorghe $e^{2,4, *,+}$, Ioana Cristina Marinaș ${ }^{2, *} \mathbb{(}$, Elisabeta Irina Geană ${ }^{5}(\mathbb{D}$, \\ Maria Iasmina Moza ${ }^{2,3,4}$, Ortansa Csutak ${ }^{1,3}$ and Mariana Carmen Chifiriuc 2,4,6,7 (D) \\ 1 Department of Genetics, Faculty of Biology, University of Bucharest, Botanical Garden, \\ 3 Intrarea Portocalelor St., 050095 Bucharest, Romania; viorica.corbu@yahoo.com (V.M.C.); \\ cs.ortansa@gmail.com (O.C.) \\ 2 Research Institute of the University of Bucharest-ICUB, 91-95 Splaiul Independentei St., District 5, \\ 050095 Bucharest, Romania; iasmina_moza@yahoo.com (M.I.M.); carmen.chifiriuc@gmail.com (M.C.C.) \\ 3 Doctoral School of Biology, University of Bucharest, 91-95 Splaiul Independenței St., District 5, \\ 050095 Bucharest, Romania \\ 4 Department of Microbiology and Immunology, Faculty of Biology, University of Bucharest, Botanical Garden, \\ 3 Intrarea Portocalelor St., District 6, 060101 Bucharest, Romania \\ 5 National R\&D Institute for Cryogenics and Isotopic Technologies-ICIT, Rm. Valcea, 4 Uzinei St., \\ 240050 Ramnicu Valcea, Romania; irina.geana@icsi.ro \\ check for \\ updates \\ Citation: Corbu, V.M.; Gheorghe, I.; \\ Marinaș, I.C.; Geană, E.I.; Moza, M.I.; \\ Csutak, O.; Chifiriuc, M.C. \\ Demonstration of Allium sativum \\ 6 Romanian Academy of Scientists, 54 Spl. Independentei St., District 5, 50085 Bucharest, Romania \\ 7 The Romanian Academy, 25, Calea Victoriei, Sector 1, District 1, 010071 Bucharest, Romania \\ * Correspondence: irina.gheorghe@bio.unibuc.ro (I.G.); ioana.cristina.marinas@gmail.com (I.C.M.) \\ + These authors have contributed equally to this work.
} Extract Inhibitory Effect on Biodeteriogenic Microbial Strain Growth, Biofilm Development, and Enzymatic and Organic Acid Production. Molecules 2021, 26, 7195 https://doi.org/10.3390/ molecules26237195

Academic Editors:

Alessandra Morana and

Giuseppe Squillaci

Received: 30 October 2021

Accepted: 24 November 2021

Published: 27 November 2021

Publisher's Note: MDPI stays neutral with regard to jurisdictional claims in published maps and institutional affiliations.

Copyright: (c) 2021 by the authors. Licensee MDPI, Basel, Switzerland. This article is an open access article distributed under the terms and conditions of the Creative Commons Attribution (CC BY) license (https:// creativecommons.org/licenses/by/ $4.0 /)$.

\begin{abstract}
To the best of our knowledge, this is the first study demonstrating the efficiency of Allium sativum hydro-alcoholic extract (ASE) againstFigure growth, biofilm development, and soluble factor production of more than 200 biodeteriogenic microbial strains isolated from cultural heritage objects and buildings. The plant extract composition and antioxidant activities were determined spectrophotometrically and by HPLC-MS. The bioevaluation consisted of the qualitative (adapted diffusion method) and the quantitative evaluation of the inhibitory effect on planktonic growth (microdilution method), biofilm formation (violet crystal microtiter method), and production of microbial enzymes and organic acids. The garlic extract efficiency was correlated with microbial strain taxonomy and isolation source (the fungal strains isolated from paintings and paper and bacteria from wood, paper, and textiles were the most susceptible). The garlic extract contained thiosulfinate (307.66 $\pm 0.043 \mu \mathrm{M} / \mathrm{g})$, flavonoids (64.33 $\pm 7.69 \mu \mathrm{g} Q E / g)$, and polyphenols $(0.95 \pm 0.011 \mathrm{mg} \mathrm{GAE} / \mathrm{g})$ as major compounds and demonstrated the highest efficiency against the Aspergillus versicolor (MIC 3.12-6.25 mg/mL), A. ochraceus (MIC: $3.12 \mathrm{mg} / \mathrm{mL}$ ), Penicillium expansum (MIC $6.25-12.5 \mathrm{mg} / \mathrm{mL}$ ), and A. niger (MIC $3.12-50 \mathrm{mg} / \mathrm{mL}$ ) strains. The extract inhibited the adherence capacity (IIBG\% 95.08-44.62\%) and the production of cellulase, organic acids, and esterase. This eco-friendly solution shows promising potential for the conservation and safeguarding of tangible cultural heritage, successfully combating the biodeteriogenic microorganisms without undesirable side effects for the natural ecosystems.
\end{abstract}

Keywords: filamentous fungi; garlic extract; biodeterioration; biocides; antifungal

\section{Introduction}

The biodeterioration of tangible cultural heritage is mainly due to fungi and bacteria, harboring a huge reservoir of microbial enzymes (e.g., cellulases, hemicellulases, endoglucanases, cellobiohydrolases, esterases, phenoloxidases, pectinases, amylases) and acids (gluconic, citric, and oxalic). Moreover, the pigment production as well as biofilm formation cause aesthetic and structural alteration or loss of cultural heritage objects and 
buildings [1]. Deterioration caused by biological agents has been reported for different classes of materials: wool, paintings, textiles, paper, parchment, leather, etc. [1-3].

In Romania, only several studies have focused on the biodeterioration of material cultural heritage and on the diversity of the involved genera and species. These studies have highlighted the presence of different filamentous fungi, such as Alternaria spp., Penicillium spp. (P. rugulosum, P. digitatum, P. brevicompactum, and P. chrysogenum), Aspergillus spp., Rhizopus spp. (R. stolonifer), Fusarium spp. (F. proliferatum), Mucor spp. (M. circinelloides), Trichoderma spp. (T. longibrachyatum), Botrytis spp., Planomicrobium spp., Cladosporium spp., Variovorax spp., and Candida spp. on wooden walls, stone walls, and mural paintings of heritage churches from different counties, as well as on different ethnographical textiles, part of the collection of The National Museum of the Romanian Peasant [1,4-10].

In this context, there is an increased necessity to develop effective and ecofriendly prevention and conservation solutions to protect the material cultural heritage against microbial (re)colonization, with low toxicity risk for human, animal, and environmental health $[11,12]$. Our research group revealed the efficiency of $\mathrm{MgB}_{2}$ ecofriendly powders against biodeteriogenic fungi isolated from wooden and stone churches and heritage objects from Romanian counties [13].

One of the valuable ecological alternatives to common synthetic antifungal agents with a relatively safe and widely accepted status, due to the low risk of side effects [11] and minimal ecotoxicity being represented by the use of plant extracts, knowing their previously demonstrated antimicrobial and antibiofilm activity against fungal and bacterial strains, causing the deterioration of cultural heritage $[14,15]$. Until the present, in Romania, there are very few studies regarding the antimicrobial activity of different plant extracts against biodeteriogenic microorganisms of cultural heritage objects and buildings [16,17] Taking into account the fact that for more than 5000 years, garlic has been recognized as a medicinal plant [18], with its antimicrobial activity mainly due to the allicin [19], this research proposes an ecofriendly solution against biodeteriogenic microorganisms on the basis of an Allium sativum extract [20].

In this context, we aimed to evaluate the capacity of the hydro-alcoholic $(50: 50, \%)$ extract of $A$. sativum to inhibit the biodeteriogenic fungi and bacteria grown in planktonic and biofilm states and to examine the effect of garlic bulb extract on the production of soluble enzymes and organic acids. The physico-chemical characterization of A. sativum extract was first performed, followed by the in vitro demonstration of the efficacy of this alternative solution on a collection of over 200 filamentous fungi and bacterial strains isolated from wooden and stone biodeteriorated heritage objects and churches from different Romanian counties.

\section{Results}

\subsection{Chemical Composition and Antioxidant Activity}

The results obtained for the total polyphenol content and antioxidant activity by different methods are shown in Table 1 . The results of the antioxidant activity of the extracts obtained by different assays are slightly different and may be due to differences in the used methods [21]. It can be noticed that the A. sativum extract had a more pronounced reducing capacity, revealed by the DPPH method, as compared to the CUPRAC and FRAP assays. The total thiosulfinate content obtained for our A. sativum fresh plant material was significantly higher than that reported by Gonzalez et al. (2009) (2.65 to $4.59 \mathrm{mM} / 100 \mathrm{~g}$ ) [22], probably due to lower processing of plant material.

The obtained chromatograms from the UHPLC-MS/MS analysis of A. sativum plant extract are shown in Figure 1a for polyphenolic compounds and Figure $1 \mathrm{~b}$ for thiosulfinate compounds. 

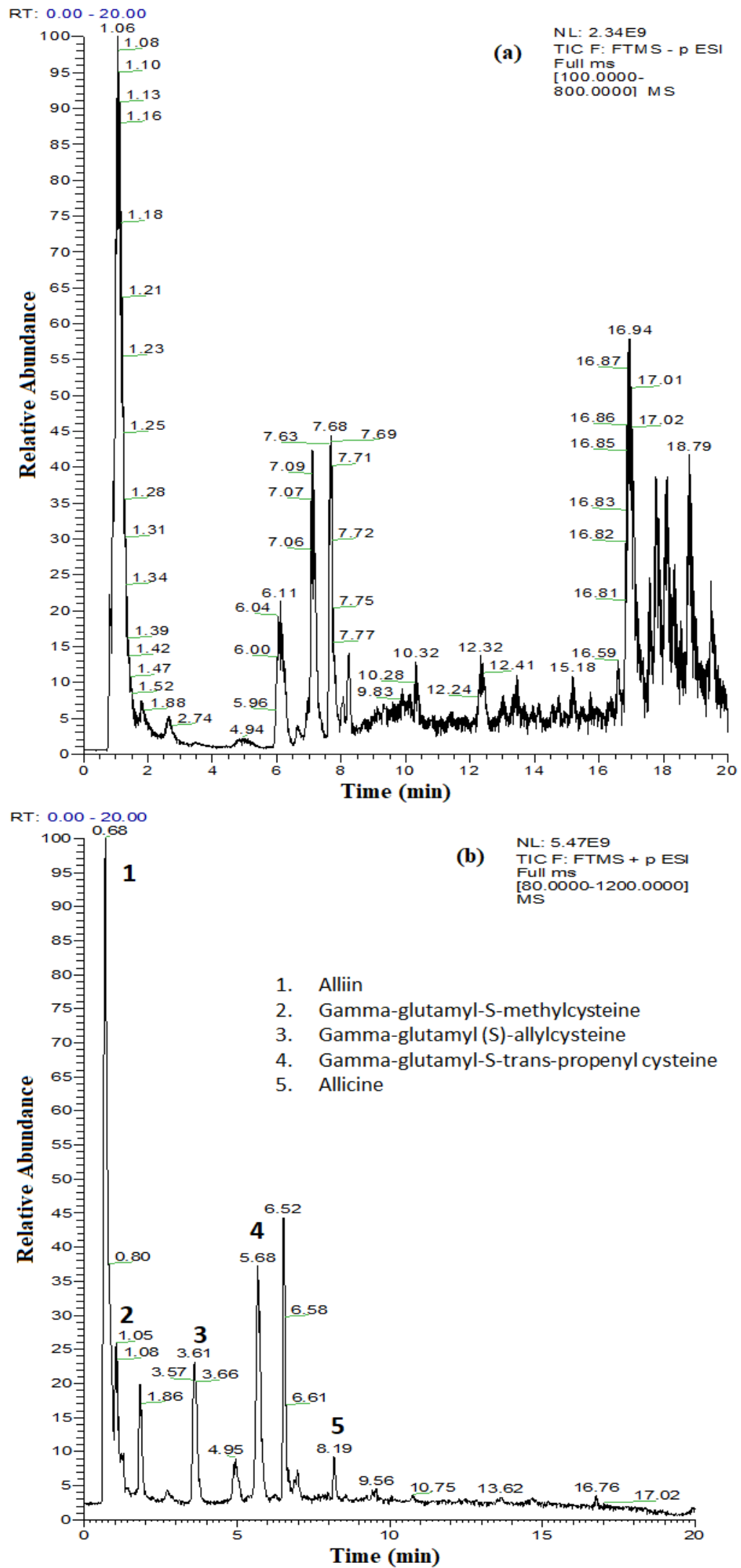

Figure 1. The obtained total ion current (TIC) chromatograms for the separation of (a) polyphenolic compounds from A. sativum plant extract by UHPLC-MS/MS detection in negative ionization mode and (b) thiosulfinate compounds from A. sativum plant extract by UHPLC-MS/MS detection in positive ionization mode. 
Table 1. The total polyphenol content (TPC) and antioxidant activity obtained by different methods.

\begin{tabular}{cc}
\hline Parameter & $\begin{array}{c}\text { The Analyzed Extract in Relation to the Quantity } \\
\text { Used (Mean } \pm \text { SD) }\end{array}$ \\
\hline TPC $(\mathrm{mg}$ GAE $/ \mathrm{g})$ & $0.95 \pm 0.011$ \\
Flavonoids $(\mu \mathrm{g}$ quercetin $/ \mathrm{g})$ & $64.33 \pm 7.69$ \\
Total thiosulfinate $(\mu \mathrm{M} / \mathrm{g})$ & $307.66 \pm 0.043$ \\
\hline Antioxidant activity & Extract $(0.1 \mathrm{~g} / \mathrm{mL})$ \\
\hline DPPH $(\mu \mathrm{M}$ Trolox $/ \mathrm{mL})$ & $66.39 \pm 5.50$ \\
CUPRAC $(\mu \mathrm{M}$ Trolox $/ \mathrm{mL})$ & $52.25 \pm 3.01$ \\
FRAP $(\mu \mathrm{M}$ Trolox $/ \mathrm{mL})$ & $43.51 \pm 1.49$ \\
\hline
\end{tabular}

Most of the phenolic compounds in the A. sativum plant extract were detected at trace levels, with concentrations below $10 \mu \mathrm{g} / \mathrm{L}$, while the contents of vanillic, $\mathrm{t}$-ferulic, and ellagic acids and epicatechin were $65.2 \mu \mathrm{g} / \mathrm{L}, 18.8 \mu \mathrm{g} / \mathrm{L}, 13.2 \mu \mathrm{g} / \mathrm{L}$, and $41.2 \mu \mathrm{g} / \mathrm{L}$, respectively (Table 2). Even if the polyphenol content of the A. sativum plant extract is low, the total of the quantified phenolic acids $(128 \mu \mathrm{g} / \mathrm{L})$ and of the quantified flavonoids $(97.2 \mu \mathrm{g} / \mathrm{L})$ guarantees the inhibitory activity on biodeteriogenic fungi spore germination and mycelium growth through the synergistic effect of the antimicrobial compounds $[23,24]$.

Table 2. Identification and quantitative data regarding the bioactive compounds in the $A$. sativum liquid extract.

\begin{tabular}{|c|c|c|c|c|c|}
\hline No. & Compound & $\begin{array}{c}\text { Retention } \\
\text { Time } \\
\text { (min) }\end{array}$ & $\begin{array}{c}\text { Accurate Mass } \\
{[\mathbf{M}-\mathbf{H}]^{-} /[\mathbf{M}-\mathbf{H}]^{+}}\end{array}$ & Mass Fragments & $\begin{array}{c}\text { Concentration } \\
(\mu \mathrm{g} / \mathrm{L})\end{array}$ \\
\hline \multicolumn{6}{|c|}{ Polyphenolic compounds by UHPLC-MS/MS in negative ionization mode } \\
\hline 1 & Gallic acid & 0.68 & 169.0133 & 125.0231 & 0.4 \\
\hline 2 & 3,4-Dihydroxybenzoic acid & 1.59 & 153.0183 & 109.0281 & 0.8 \\
\hline 3 & 4-Hydroxybenzoic acid & 5.40 & 137.0232 & 93.0331 & 4 \\
\hline 4 & Chlorogenic acid & 7.55 & 353.0879 & 191.0553 & 0.8 \\
\hline 5 & Syringic acid & 8.03 & 197.0450 & $\begin{array}{c}182.0212,166.9976 \\
153.0547,138.0311 \\
123.0075\end{array}$ & 7.2 \\
\hline 6 & Caffeic acid & 8.08 & 179.0338 & 135.044 & 6.4 \\
\hline 7 & Vanillic acid & 8.31 & 167.0343 & $\begin{array}{c}152.0105,124.0154 \\
111.0075,139.0025 \\
95.0125\end{array}$ & 65.2 \\
\hline 8 & $p$-Coumaric acid & 8.59 & 163.0392 & 119.0489 & 1.2 \\
\hline 9 & $t$-Ferulic acid & 8.83 & 193.0500 & $178.0262,134.0361$ & 18.8 \\
\hline 10 & Ellagic acid & 9.66 & 300.9990 & 300.9990 & 13.2 \\
\hline 11 & Cinnamic acid & 10.45 & 147.0441 & $119.0489,103.0387$ & 7.6 \\
\hline 12 & Abscisic acid & 10.04 & 263.1288 & $179.9803,191.9454$ & 2.4 \\
\hline \multicolumn{5}{|c|}{$\Sigma$ phenolic acids } & 128 \\
\hline 13 & Epi-catechin & 7.98 & 289.0719 & $\begin{array}{l}109.0282,125.0232 \\
137.0232,151.0390 \\
203.0708,245.0817\end{array}$ & 41.2 \\
\hline 14 & Quercetin & 10.74 & 301.0356 & $\begin{array}{l}\text { 151.0226, 178.9977, } \\
121.0282,107.0125\end{array}$ & 0.8 \\
\hline 15 & Naringin & 9.25 & 579.1718 & 363.0721 & 3.6 \\
\hline 16 & Hesperidin & 9.37 & 609.1824 & 377.0876 & 14 \\
\hline 17 & Rutin & 9.43 & 609.1462 & 3345.0614 & 10 \\
\hline 18 & Kaempferol & 11.62 & 285.0406 & $151.0389,117.0180$ & 2.8 \\
\hline 19 & Isorhamnetin & 11.80 & 315.0512 & 300.0276 & 9.6 \\
\hline 20 & Apigenin & 11.86 & 269.0457 & $\begin{array}{c}117.0333,151.0027 \\
107.0126\end{array}$ & 4.4 \\
\hline 21 & Pinocembrin & 12.70 & 255.0663 & $\begin{array}{c}213.0551,151.0026 \\
107.0125\end{array}$ & 1.6 \\
\hline
\end{tabular}


Table 2. Cont.

\begin{tabular}{|c|c|c|c|c|c|}
\hline No. & Compound & $\begin{array}{l}\text { Retention } \\
\text { Time } \\
\text { (min) }\end{array}$ & $\begin{array}{c}\text { Accurate Mass } \\
{[\mathbf{M}-\mathbf{H}]^{-} /[\mathbf{M}-\mathbf{H}]^{+}}\end{array}$ & Mass Fragments & $\begin{array}{c}\text { Concentration } \\
(\mu \mathrm{g} / \mathrm{L})\end{array}$ \\
\hline 22 & Chrysin & 13.52 & 253.0506 & $\begin{array}{c}143.0491,145.0284 \\
107.0125,209.0603 \\
63.0226,65.0019\end{array}$ & 3.6 \\
\hline 23 & Galangin & 13.77 & 269.0458 & $169.0650,143.0491$ & 2.8 \\
\hline 24 & Pinostrobin & 14.84 & 269.081 & 179.0554 & 2.8 \\
\hline \multicolumn{5}{|c|}{$\Sigma$ flavonoids } & 97.2 \\
\hline 25 & $t$-Resveratrol & 9.55 & 227.0707 & $185.0813,143.0337$ & 0.8 \\
\hline \multicolumn{6}{|c|}{ Thiosulfinate compounds by UHPLC-MS/MS in positive ionization mode } \\
\hline 1 & Alliin & 0.68 & 178.0530 & $175.1188,116.0709$ & - \\
\hline 2 & $\begin{array}{l}\text { Gamma-glutamyl-S- } \\
\text { methylcysteine }\end{array}$ & 1.05 & 265.0850 & $182.0811,132.1020$ & - \\
\hline 3 & $\begin{array}{l}\text { Gamma-glutamyl } \\
\text { (S)-allylcysteine }\end{array}$ & 3.61 & 291.1005 & $162.0582,139.0502$ & - \\
\hline 4 & $\begin{array}{c}\text { Gamma-glutamyl-S-trans- } \\
\text { propenyl } \\
\text { cysteine }\end{array}$ & 5.68 & 291.1006 & 162.0582 & - \\
\hline 5 & Allicin & 8.19 & 163.0245 & 120.9779 & - \\
\hline
\end{tabular}

In the absence of standards, identification of other compounds in the A. sativum plant extract was based on the search for the protonated molecules $[\mathrm{M}-\mathrm{H}]^{+}$and comparisons with the specific literature. The exact mass search using ChemSpider reference library enabled us to identify thiosulfinated compounds with antimicrobial activity (alliin, gammaglutamyl-S-methyl cysteine, gamma-glutamyl-(S)-allyl cysteine, gamma-glutamyl-S-transpropenyl cysteine, and allicin) (Figure 1b, Table 2). The reactivity of thiosulfinates to the thiol groups is an important component of the antimicrobial activity. In the case of allicin, in addition to being redox-active, it is quite lipophilic, allowing for the permeability of cell membranes. It has been demonstrated that allicin is able to form transient pores in artificial membranes and bio-membranes [25-27]. The identification of allicin in the A. sativum plant extract (TIC, extracted chromatogram and the extracted ion chromatogram for $m / z$ 163.0245) is presented in Figure S1.

Because the content of phenolic compounds is low, we can assume that the antioxidant activity is due to organosulfur compounds.

\subsection{Qualitative Screening of the Antimicrobial Activity}

\subsubsection{Antifungal Activity}

A total number of 152 filamentous fungi strains previously isolated from wooden and stone churches (narthex, nave, altar) as well as from museum objects (paper, textiles, and paintings) and characterized by MALDI-TOF mass spectrometry were used in this study. These strains belong to eight genera with 19 species (Penicillium chrysogenum, P. corylophylum, P. expansum, P. digitatum, Aspergillus niger, A. flavus, A. clavatus, A. nidulans, A. ochraceus, A. versicolor, A. ustus, A. sydowi, Rhizopus oryzae, Trichoderma orientale, Byssochlamys spectabilis, Alternaria alternata, Purpureocillium lilacinum, Fusarium proliferatum, F. cerealis culmorum group, Cladosporium spp.). The strains belonging to the Penicillium and Aspergillus genera were the most frequently isolated from the heritage objects and churches. The qualitative (adapted disc diffusion) method was used for the screening of the antimicrobial activity of the $A$. sativum plant extract. The antimicrobial activity of the tested plant extract against the tested microfungi demonstrated a very high efficiency against most of the tested strains (Figures 2, 3 and S2). The garlic extract was more efficient than the used solvent in terms of inhibitory effect, with more than 100 tested fungal strains responding to the extract treatment with the occurrence of a growth inhibition zones larger than $10 \mathrm{~mm}$ as compared to only 11 strains in case of the solvent (Figure 2). 


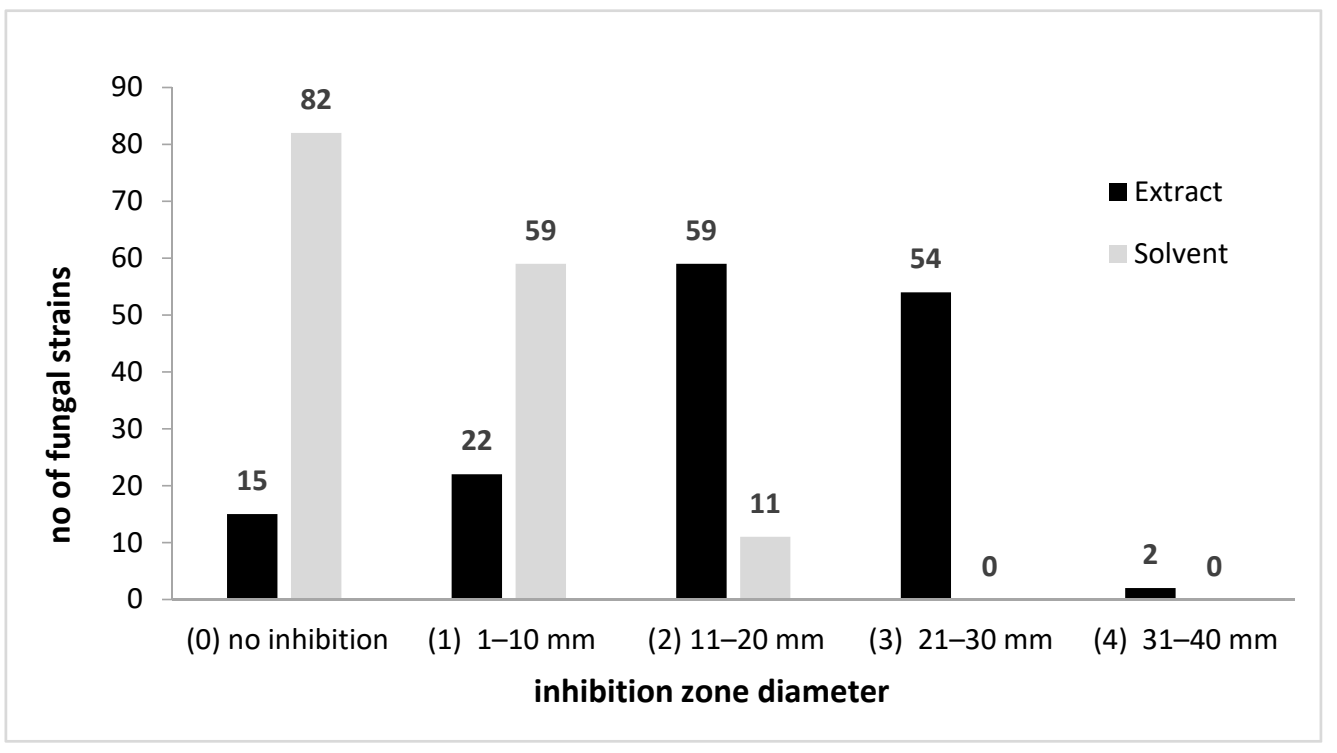

Figure 2. A. sativum inhibitory activity against fungal strains expressed by arbitrary units of growth inhibition zone diameter.

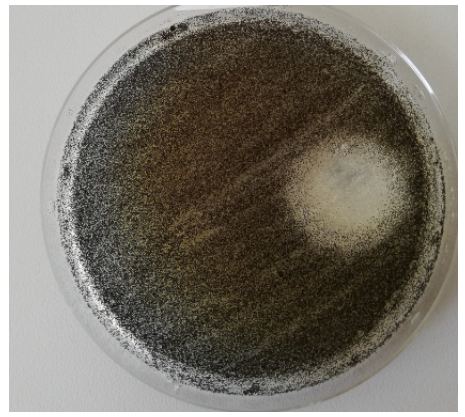

(a)

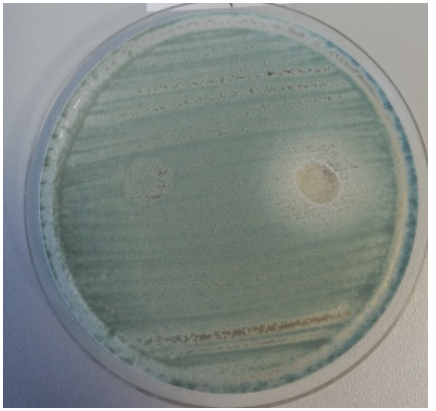

(b)

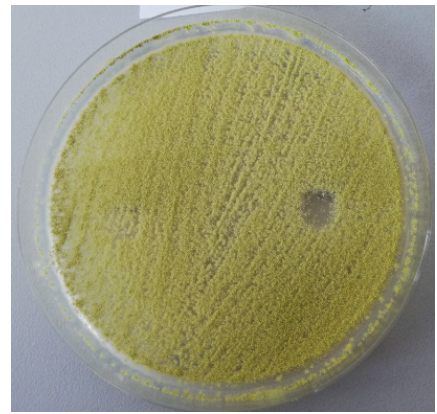

(c)

Figure 3. Example of the disk diffusion screening assay of the antimicrobial activity of the tested A. sativum extract against A. niger (a), P. chrysogenum (b), and A. flavus (c) strains isolated from the wooden churches (the obverse of the colonies).

\subsubsection{Antibacterial Activity}

The qualitative screening of the antimicrobial activity of the A. sativum plant extract was also performed against 62 bacterial strains previously isolated from biodeteriorated wooden, stone, textile, or paper objects. These strains belong to four genera and 10 species (Bacillus pumilus, B. megaterium, B. subtilis, B. cereus, B. atrophaeus, B. thuringiensis, Pseudomonas koreensis, R. erythrophyllus, Arthrobacter globiformis, A. aurascens). The garlic extract revealed a very high efficiency on most bacterial strains; the inhibitory effect, with only few exceptions (eight strains mainly isolated from the external surfaces of the wooden churches), was due to the extract and not to the solvent (Figures 4, 5 and S2).

\subsection{Quantitative Evaluation of the Antimicrobial Activity}

\subsubsection{Antifungal Activity}

For this step, the plant extract was tested for its antifungal activity against the most susceptible strains, as evidenced in the screening assay. Therefore, the efficiency of $A$. sativum hydro-alcoholic extract was expressed by the MIC values that were determined using the binary serial dilution method. The strains that responded better to the treatment were identified as B. spectabilis, Cladosporium spp., and T. orientale, and at the opposite side, the 
strains belonging to the Alternaria, Penicillium and Aspergillus genera were less susceptible, with MIC approximately two times higher than the average values (Figure 6).

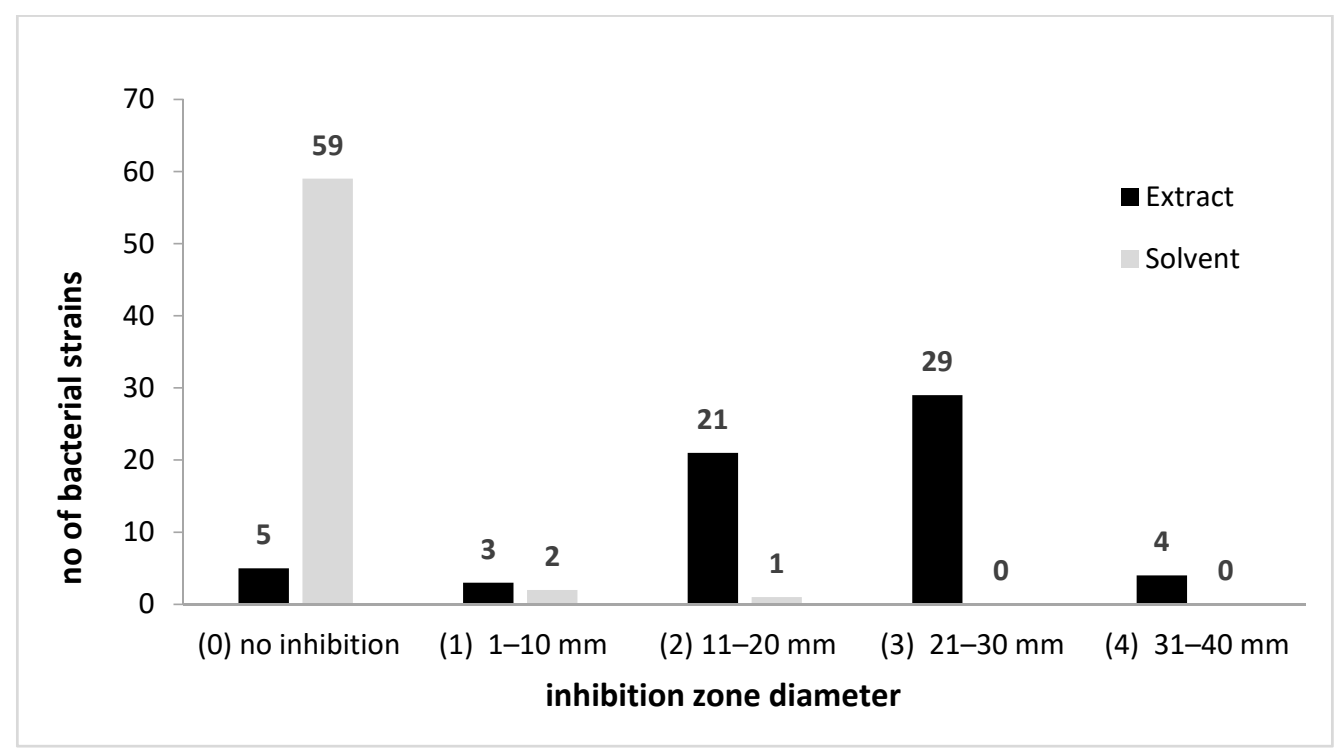

Figure 4. A. sativum inhibitory activity against bacterial strains expressed by arbitrary units of growth inhibition zone diameter.
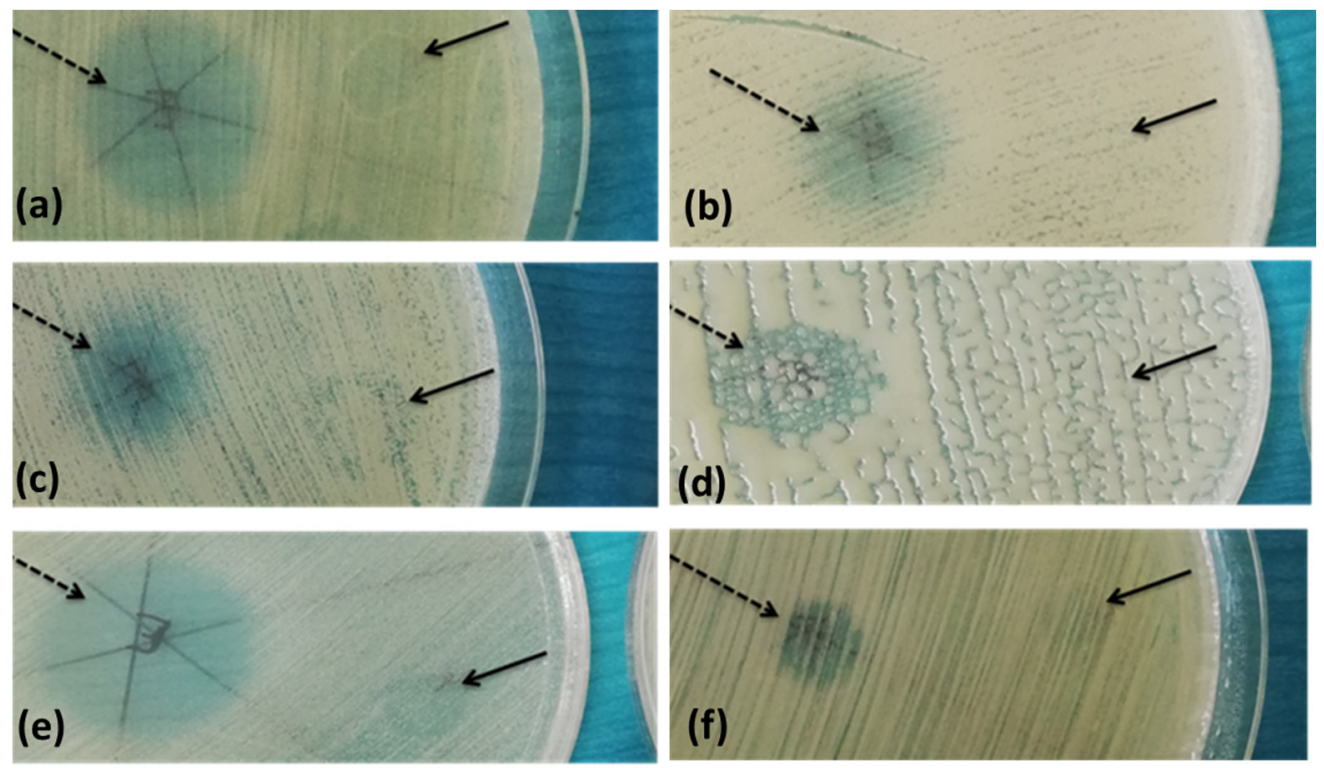

Figure 5. Example of the disk diffusion screening assays of the antimicrobial activity of the tested A. sativum extract against B. cereus (a), B. pumilus (b,c), B. megaterium $(\mathbf{d})$, R. erythrophyllus $(\mathbf{e})$, A. globiformis (f) strains; dashed arrow-A. sativum inhibition zone, full arrow-solvent inhibition zone.

Regarding the MIC distribution for different species of the two most frequently encountered genera involved in the biodeterioration of the cultural heritage churches and objects (Penicillium spp. and Aspergillus spp.) (Figure 7), it was shown that A. sativum plant extract demonstrated the highest efficiency against $A$. ochraceus (MIC $=3.12 \mathrm{mg} / \mathrm{mL}$ ) and A. versicolor strains (MIC $=4.16 \mathrm{mg} / \mathrm{mL}$ ), followed by the P. expansum and A. niger strains. 


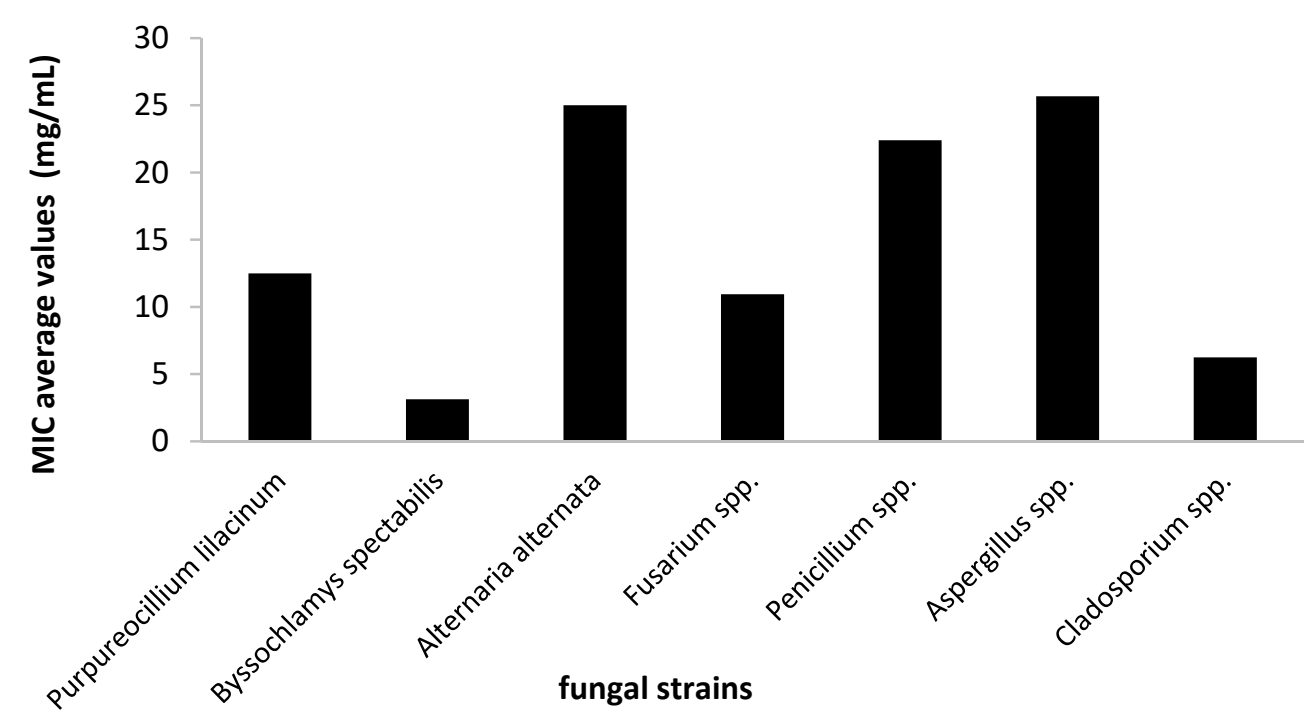

Figure 6. Average values of minimal inhibitory concentration (MIC) of A. sativum extract obtained on the tested fungi.

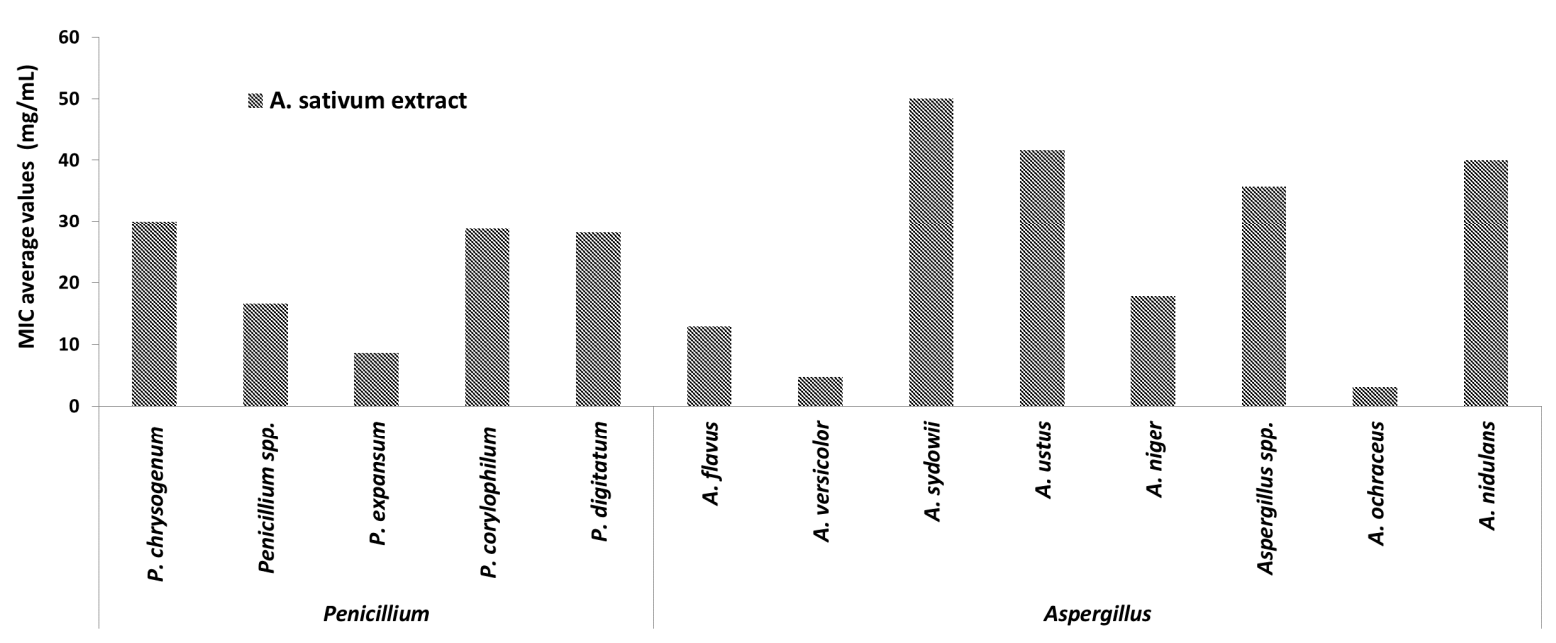

Figure 7. Average values of minimal inhibitory concentration (MIC) of A. sativum extract on strains belonging to Penicillium and Aspergillus genera.

The MIC value distribution by isolation sources demonstrated that the most susceptible strains were from the biodeteriorated paper $(\mathrm{MIC}=7.81 \mathrm{mg} / \mathrm{mL}$ ), while the least susceptible were from textiles and stone materials (MIC $=26.33 \mathrm{mg} / \mathrm{mL}$ and $22.5 \mathrm{mg} / \mathrm{mL}$ ) (Figure 8).

The activity of $A$. satioum extract against Penicillium spp. was significantly higher in comparison with that of the solvent activity for strains isolated from different sources: wooden $(p<0.00001)$, painting $(p<0.05)$, stone $(p<0.05)$, and textiles $(p<0.05)$. In the case of Aspergillus spp., the antimicrobial activity of A. sativum extract was significantly higher than that of the solvent for wooden $(p<0.001)$ and textile $(p<0.05)$ strains. Moreover, statistically significant MIC values of the extract compared to the solvent control were obtained for wood strains belonging to Fusarium $(p<0.05)$ and Cladosporium $(p<0.05)$ genera.

\subsubsection{Antibacterial Activity}

The quantitative evaluation of the antimicrobial efficiency of $A$. sativum hydro-alcoholic extract against bacterial strains revealed the highest efficiency against $R$. erythrophyllus and B. thuringiensis strains (MIC $=3.12 \mathrm{mg} / \mathrm{mL}$ ) (Figure 9). 


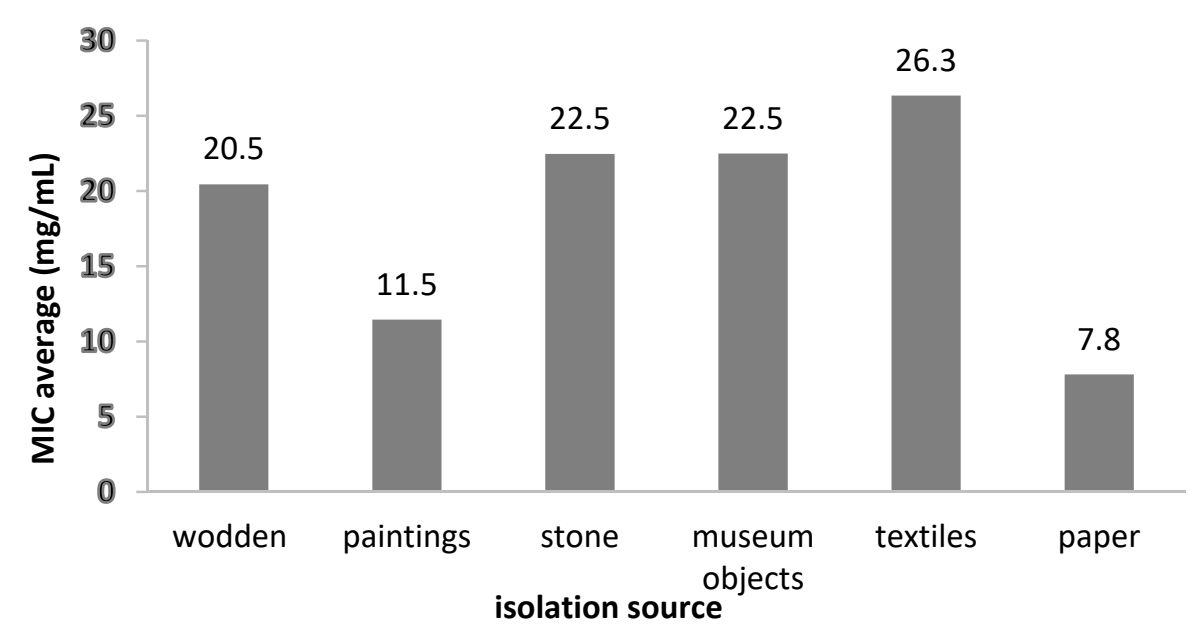

Figure 8. The average MIC values of the A. sativum extract on fungal strains, depending on the isolation sources.

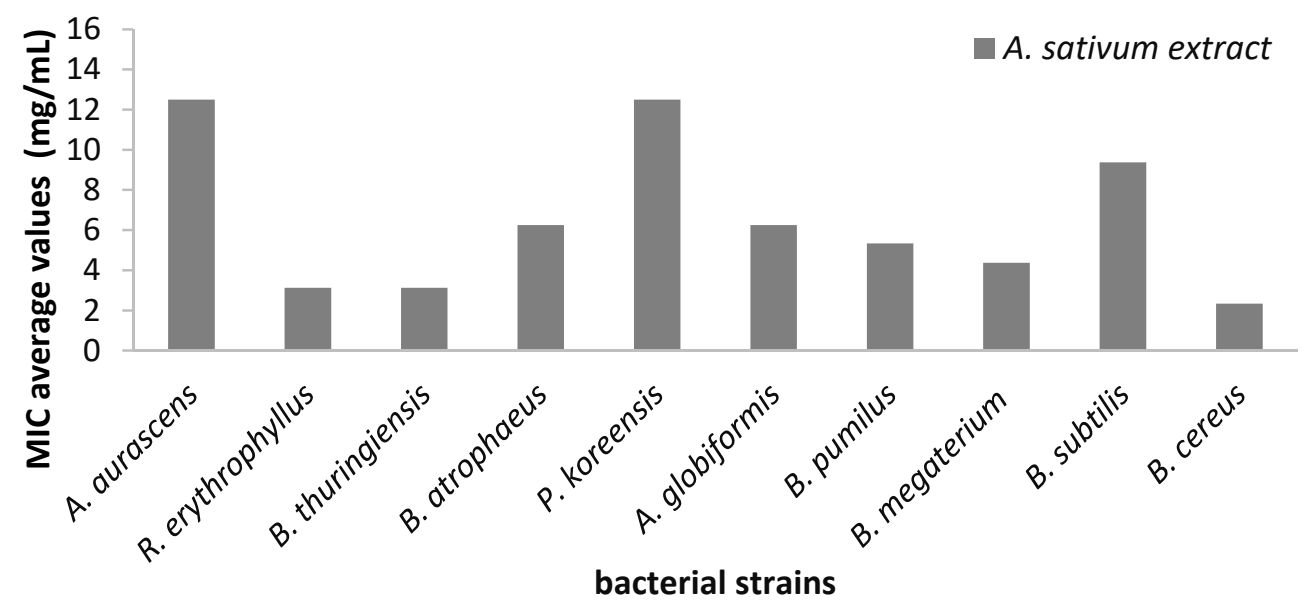

Figure 9. Average values of minimal inhibitory concentration (MIC) of A. sativum extract on different bacterial strains.

Regarding the MIC values distribution by the isolation source, we showed that the most susceptible strains were the isolates from the museum collections (MIC $=3.64$ $\mathrm{mg} / \mathrm{mL}$ ), while those from mural paintings were the least susceptible (MIC $=12.5 \mathrm{mg} / \mathrm{mL}$ ) (Figure 10).

In the case of bacterial strains, a statistically significant difference was observed between the activity of the extract and solvent for Bacillus spp. strains isolated from wood $(p<0.01)$ and stone $(p<0.01)$. In addition, for the Purpureocillum spp. strains isolated only from stone, the difference between the solvent control and extract was also significant $(p<0.05)$.

\subsection{Antibiofilm Activity}

In Table 3, the fungal strains isolated from textiles showed the ability to adhere to the inert surface. Among the isolated fungi, it was observed that 2 out of the tested 17 strains did not show the ability to adhere to the inert substratum. In the case of adherent strains, the extract inhibited the microbial adhesion, with the inhibition index of biofilm growth (IIBG) varying from $80.47 \pm 2.73$ to $95.08 \pm 0.91$. In the case of bacterial strains, from the 19 tested strains, only three had the capacity to form microbial biofilms, all being inhibited with an IIBG of $44.62 \pm 7.30$ to $87.56 \pm 4.60$. Apart from two strains (P. chrysogenum from wood and B. arthopahaeus from stone), in all cases, the extract was proven to be more efficient than the solvent, with the results being statistically significant. 


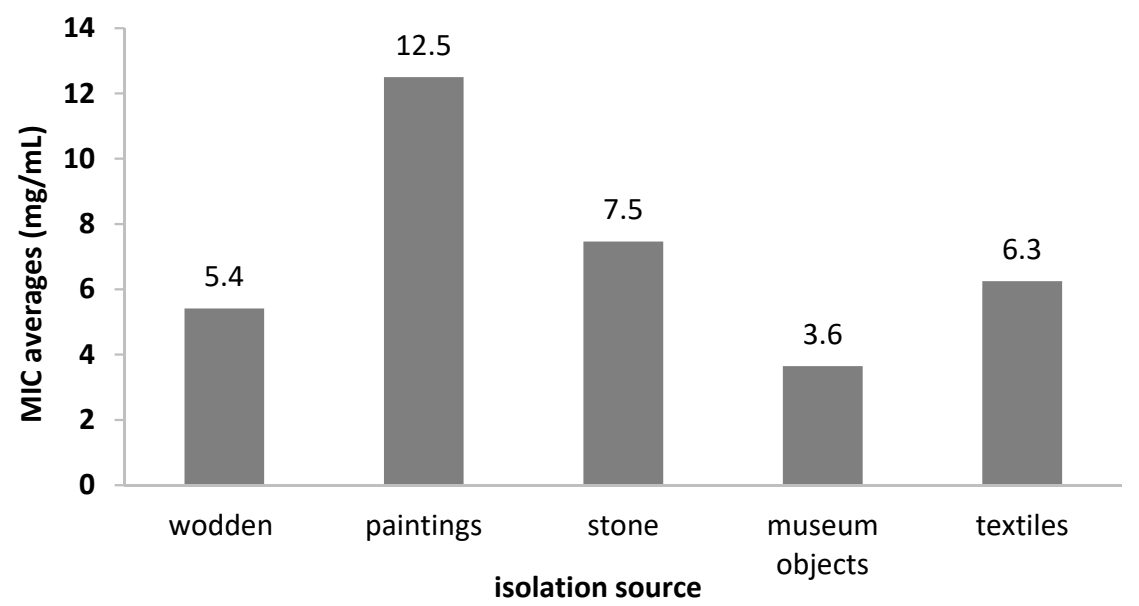

Figure 10. The average MIC values of the A. sativum extract depending on bacterial strain isolation sources.

Table 3. The MIC and MBEC values of the A. sativum hydro-alcoholic extract.

\begin{tabular}{|c|c|c|c|c|c|}
\hline Species & Isolation Source & $\begin{array}{c}\mathrm{MIC} \\
(\mathrm{mg} / \mathrm{mL})\end{array}$ & $\begin{array}{l}\text { MBEC } \\
(\mathrm{mg} / \mathrm{mL})\end{array}$ & IIBG $^{2}(\%)$ & $\begin{array}{c}p \text { Value (Relative to Solvent } \\
\text { Control) }\end{array}$ \\
\hline A. niger & textiles & 25 & 25 & $95.08 \pm 0.91$ & $<0.0001$ \\
\hline P. chrysogenum & textiles & 25 & 6.25 & $89.11 \pm 0.91$ & $<0.01$ \\
\hline Penicilium spp. & stone & 25 & 12.5 & $90.71 \pm 0.70$ & $<0.001$ \\
\hline P. corylophilum & textiles & 25 & 6.25 & $80.47 \pm 2.73$ & $<0.05$ \\
\hline A. flavus & textiles & 25 & 12.5 & $88.57 \pm 1.30$ & $<0.01$ \\
\hline Aspergillus spp. & stone & 25 & 6.25 & $90.26 \pm 1.01$ & $<0.000001$ \\
\hline A. sydowii & stone & 50 & 12.5 & $93.54 \pm 1.09$ & $<0.01$ \\
\hline A. niger & wood & 6.25 & 12.5 & $88.74 \pm 1.31$ & $<0.001$ \\
\hline A. flavus & textiles & 12.5 & 6.25 & $88.19 \pm 2.40$ & $<0.01$ \\
\hline P. lilacium & stone & 12.5 & & NA & \\
\hline P. lilacium & stone & 12.5 & & NA & \\
\hline Aspergillus spp. & stone & 25 & 25 & $84.28 \pm 1.86$ & $<0.01$ \\
\hline P. chrysogenum & wood & 50 & 12.5 & $93.87 \pm 0.03$ & 0.072 \\
\hline P. corylophilum & wood & 12.5 & 6.25 & $92.50 \pm 0.00$ & $<0.00001$ \\
\hline P. corylophilum & wood & 6.25 & 12.5 & $92.30 \pm 1.92$ & $<0.0001$ \\
\hline P. corylophilum & wood & 25 & 12.5 & $93.42 \pm 1.38$ & $<0.001$ \\
\hline A. niger & textiles & 25 & 12.5 & $91.96 \pm 0.71$ & $<0.001$ \\
\hline B. megaterium & wood & 6.25 & & NA & \\
\hline B. subtilis & wood & 6.25 & & NA & \\
\hline B. cereus & ceramic & 1.56 & & NA & \\
\hline B. pumilus & wood & 0.78 & & NA & \\
\hline P. koreensis & stone & 12.5 & & NA & \\
\hline B. arthopahaeus & stone & 6.25 & 12.5 & $44.62 \pm 7.30$ & 0.342 \\
\hline B. megaterium & wood & 3.125 & & NA & \\
\hline B. thuringiensis & stone & 3.125 & 12.5 & $87.56 \pm 4.60$ & $<0.01$ \\
\hline B. pumilus & stone & 6.25 & & NA & \\
\hline A. aurascens & wood & 12.5 & & NA & \\
\hline B. cereus & wood & 3.125 & & NA & \\
\hline B. megaterium & wood & 3.125 & & NA & \\
\hline B. megaterium & wood & 3.125 & & NA & \\
\hline B. pumilus & painting & 12.5 & & NA & \\
\hline R. erythrophilus & wood & 3.125 & & NA & \\
\hline B. pumilus & wood & 3.125 & & NA & \\
\hline B. megaterium & textiles & 6.25 & & NA & \\
\hline A. globiformis & wood & 6.25 & & NA & \\
\hline B. cereus & wood & 6.25 & 12.5 & $57.72 \pm 5.11$ & $<0.05$ \\
\hline
\end{tabular}

\footnotetext{
${ }^{1}$ MBEC—-minimum biofilm eradication concentration on inert substrate; ${ }^{2}$ IIBG-inhibition index of biofilm growth; NA—non-adherent.
} 


\subsection{Effects of A. sativum Extract on Microbial Soluble Factor Production}

Among the tested fungal strains, $34.21 \%$ produced cellulases, $52.63 \%$ produced acids, and $34.21 \%$ produced esterase. No biodeteriogenic strain produced phenoloxidases.

The A. sativum extract inhibited or stimulated the production of biodeteriorating factors (cellulase, phenoloxidase, esterase, and organic acids), with the effect depending on the tested microbial strain. A. sativum extract inhibited cellulase production in the case of $61.54 \%$, decreased acidity for $55 \%$, and inhibited esterase production for $23.08 \%$ from the total of tested fungal strains. Cellulase inhibition was identified, especially for strains isolated from stone and textile, while acidity was reduced for strains isolated from wood and textile.

Table 4 shows only the variants for which differences were observed compared to the untreated strain control. The A. sativum extract significantly inhibited the cellulase production in the case of four fungal strains (Aspergillus spp., Penicilium spp., and two P. corylophilum), the esterase production in one bacterial (B. subtilis) and three fungal strains (two Aspergillus spp., one A. flavus), and the organic acid production in the case of seven fungal (two A. niger, two P. chrysogenum, one A. sydowii, P. lilacium, and Aspergillus spp.) and two bacterial strains (B. megaterium and B. cereus) $(p<0.05)$.

Table 4. The influence of $A$. sativum extract and ethanol (50\%) control on the production of enzymatic factors involved in biodeterioration.

\begin{tabular}{|c|c|c|c|c|c|c|c|c|c|c|}
\hline \multicolumn{11}{|c|}{ Fungal Strains } \\
\hline \multirow[b]{2}{*}{ Species } & \multirow[b]{2}{*}{$\begin{array}{c}\text { Isolation } \\
\text { Sources }\end{array}$} & \multicolumn{3}{|c|}{ Cellulase } & \multicolumn{3}{|c|}{ Esterase } & \multicolumn{3}{|c|}{ Acid Production } \\
\hline & & $\begin{array}{c}\text { A. } \\
\text { sativum } \\
\text { Extract }\end{array}$ & $\begin{array}{c}\text { Ethanol } \\
50 \%\end{array}$ & $p$-Value & $\begin{array}{c}\text { A. } \\
\text { sativum } \\
\text { Extract }\end{array}$ & $\begin{array}{c}\text { Ethanol } \\
50 \%\end{array}$ & $p$-Value & $\begin{array}{c}A . \\
\text { Sativum } \\
\text { Extract }\end{array}$ & $\begin{array}{c}\text { Ethanol } \\
50 \%\end{array}$ & $p$-Value \\
\hline A. niger & textile & $\begin{array}{c}105.00 \pm \\
8.66\end{array}$ & $\begin{array}{c}140.00 \pm \\
17.32\end{array}$ & 0.0535 & $\begin{array}{c}66.67 \pm \\
4.44\end{array}$ & $\begin{array}{c}58.97 \pm \\
4.44\end{array}$ & 0.1012 & $\begin{array}{c}79.09 \pm \\
3.86\end{array}$ & $\begin{array}{c}92.73 \pm \\
0.00\end{array}$ & $<0.05$ \\
\hline $\begin{array}{l}\text { P. chryso- } \\
\text { genum }\end{array}$ & textile & $\begin{array}{c}111.77 \pm \\
5.09\end{array}$ & $\begin{array}{c}108.82 \pm \\
5.09\end{array}$ & 0.5185 & - & - & - & $\begin{array}{c}70.37 \pm \\
8.49\end{array}$ & $\begin{array}{c}98.15 \pm \\
3.21\end{array}$ & $<0.05$ \\
\hline $\begin{array}{l}\text { Penicilium } \\
\text { spp. }\end{array}$ & stone & $\begin{array}{c}272.73 \pm \\
0.01\end{array}$ & $\begin{array}{c}327.27 \pm \\
0.05\end{array}$ & $<0.0001$ & $\begin{array}{c}78.26 \pm \\
13.04\end{array}$ & $\begin{array}{c}86.96 \pm \\
19.92\end{array}$ & 0.5666 & $\begin{array}{c}116.67 \pm \\
5.77\end{array}$ & $\begin{array}{c}96.67 \pm \\
11.55\end{array}$ & 0.0765 \\
\hline $\begin{array}{l}\text { P. cory- } \\
\text { lophilum }\end{array}$ & textile & $\begin{array}{c}105.56 \pm \\
7.86\end{array}$ & $\begin{array}{c}107.41 \pm \\
6.42\end{array}$ & 0.7683 & - & - & - & - & - & - \\
\hline A. flavus & textile & - & - & - & $\begin{array}{c}108.00 \pm \\
0.00\end{array}$ & $\begin{array}{c}88.00 \pm \\
6.93\end{array}$ & $<0.05$ & $\begin{array}{c}83.91 \pm \\
7.18\end{array}$ & $\begin{array}{c}81.61 \pm \\
3.98\end{array}$ & 0.6596 \\
\hline $\begin{array}{c}\text { Aspergillus } \\
\text { spp. }\end{array}$ & stone & $\begin{array}{c}108.16 \pm \\
3.53\end{array}$ & $\begin{array}{c}106.16 \pm \\
12.75\end{array}$ & 0.8113 & - & - & - & $\begin{array}{c}72.00 \pm \\
12.00\end{array}$ & $\begin{array}{l}104 \pm \\
18.33\end{array}$ & 0.0746 \\
\hline A. sydowii & stone & $\begin{array}{c}143.75 \pm \\
8.84\end{array}$ & $\begin{array}{c}150.00 \pm \\
21.65\end{array}$ & 0.1918 & - & - & - & $\begin{array}{c}68.18 \pm \\
6.43\end{array}$ & $\begin{array}{c}60.61 \pm \\
5.24\end{array}$ & 0.6788 \\
\hline A. niger & wood & - & - & - & - & - & - & $\begin{array}{c}92.00 \pm \\
13.86\end{array}$ & $\begin{array}{c}136.00 \pm \\
6.93\end{array}$ & $<0.05$ \\
\hline A. flavus & textile & $\begin{array}{c}87.50 \pm \\
8.66\end{array}$ & $\begin{array}{c}90.00 \pm \\
12.99\end{array}$ & 0.7972 & $\begin{array}{c}97.96 \pm \\
6.12\end{array}$ & $\begin{array}{c}79.59 \pm \\
0.00\end{array}$ & $<0.05$ & $\begin{array}{c}63.16 \pm \\
0.00\end{array}$ & $\begin{array}{c}68.42 \pm \\
4.56\end{array}$ & 0.1835 \\
\hline P. lilacium & stone & $\begin{array}{c}76.92 \pm \\
0.00\end{array}$ & $\begin{array}{c}100.00 \pm \\
10.88\end{array}$ & 0.0667 & $\begin{array}{c}94.44 \pm \\
9.62\end{array}$ & $\begin{array}{c}111.11 \pm \\
9.62\end{array}$ & 0.1012 & $\begin{array}{c}110.71 \pm \\
6.19\end{array}$ & $\begin{array}{c}103.57 \pm \\
6.19\end{array}$ & 0.2302 \\
\hline P. lilacium & stone & $\begin{array}{c}118.52 \pm \\
16.97\end{array}$ & $\begin{array}{c}133.33 \pm \\
0.00\end{array}$ & 0.4226 & $\begin{array}{c}93.75 \pm \\
0.00\end{array}$ & $\begin{array}{c}87.50 \pm \\
10.83\end{array}$ & 0.2697 & $\begin{array}{c}137.5 \pm \\
5.41\end{array}$ & $\begin{array}{c}118.75 \pm \\
5.41\end{array}$ & $<0.05$ \\
\hline $\begin{array}{c}\text { Aspergillus } \\
\text { spp. }\end{array}$ & stone & $\begin{array}{c}97.50 \pm \\
13.00\end{array}$ & $\begin{array}{c}60.00 \pm \\
7.50\end{array}$ & $<0.05$ & $\begin{array}{c}94.29 \pm \\
0.00\end{array}$ & $\begin{array}{c}62.86 \pm \\
4.95\end{array}$ & $<0.01$ & $\begin{array}{c}76.67 \pm \\
5.77\end{array}$ & $\begin{array}{l}130 \pm \\
17.32\end{array}$ & $<0.05$ \\
\hline $\begin{array}{l}\text { P. chryso- } \\
\text { genum }\end{array}$ & wood & $\begin{array}{c}93.94 \pm \\
6.31\end{array}$ & $\begin{array}{c}93.94 \pm \\
9.26\end{array}$ & $>1$ & - & - & - & $\begin{array}{c}82.14 \pm \\
6.19\end{array}$ & $\begin{array}{c}60.71 \pm \\
6.19\end{array}$ & $<0.05$ \\
\hline $\begin{array}{l}\text { P. cory- } \\
\text { lophilum }\end{array}$ & wood & $\begin{array}{c}126.67 \pm \\
11.55\end{array}$ & $\begin{array}{c}70.00 \pm \\
14.14\end{array}$ & $<0.01$ & - & - & - & $\begin{array}{c}144.44 \pm \\
19.25\end{array}$ & $\begin{array}{c}120.83 \pm \\
5.89\end{array}$ & 0.1589 \\
\hline $\begin{array}{l}\text { P. cory- } \\
\text { lophilum }\end{array}$ & wood & $\begin{array}{c}71.80 \pm \\
11.75\end{array}$ & $\begin{array}{c}97.44 \pm \\
8.88\end{array}$ & $<0.05$ & - & - & - & - & - & - \\
\hline A. niger & textile & - & - & - & - & - & - & $\begin{array}{c}138.46 \pm \\
0.01\end{array}$ & $\begin{array}{c}115.39 \pm \\
0.11\end{array}$ & $<0.0001$ \\
\hline
\end{tabular}


Table 4. Cont.

\begin{tabular}{|c|c|c|c|c|c|c|c|c|c|c|}
\hline \multicolumn{11}{|c|}{ Bacterial Strains } \\
\hline \multirow[b]{2}{*}{ Species } & \multirow[b]{2}{*}{$\begin{array}{l}\text { Isolation } \\
\text { Sources }\end{array}$} & \multicolumn{3}{|c|}{ Cellulase } & \multicolumn{3}{|c|}{ Esterase } & \multicolumn{3}{|c|}{ Acid Production } \\
\hline & & $\begin{array}{c}\text { A. } \\
\text { sativum } \\
\text { Extract }\end{array}$ & $\begin{array}{c}\text { Ethanol } \\
50 \%\end{array}$ & $p$-Value & $\begin{array}{c}\text { A. } \\
\text { sativum } \\
\text { Extract }\end{array}$ & $\begin{array}{c}\text { Ethanol } \\
50 \%\end{array}$ & $p$-Value & $\begin{array}{c}A . \\
\text { sativum } \\
\text { Extract }\end{array}$ & $\begin{array}{c}\text { Ethanol } \\
50 \%\end{array}$ & $p$-Value \\
\hline $\begin{array}{l}\text { B. mega- } \\
\text { terium }\end{array}$ & wood & - & - & - & $\begin{array}{c}120.00 \pm \\
0.00\end{array}$ & $\begin{array}{c}90.00 \pm \\
42.43\end{array}$ & 0.3454 & $\begin{array}{c}100.00 \pm \\
11.47\end{array}$ & $\begin{array}{c}105.00 \pm \\
7.50\end{array}$ & 0.5667 \\
\hline B. subtilis & wood & - & - & - & $\begin{array}{c}100.00 \pm \\
21.65\end{array}$ & 0 & $<0.05$ & - & - & - \\
\hline $\begin{array}{c}P . \\
\text { koreensis }\end{array}$ & stone & - & - & - & - & - & - & $\begin{array}{c}89.80 \pm \\
3.53\end{array}$ & $\begin{array}{c}95.92 \pm \\
3.53\end{array}$ & 0.1013 \\
\hline $\begin{array}{l}\text { B. arthopa- } \\
\text { haeuss }\end{array}$ & stone & - & - & - & $\begin{array}{c}71.43 \pm \\
12.37\end{array}$ & $\begin{array}{c}78.57 \pm \\
12.37\end{array}$ & 0.5186 & - & - & - \\
\hline $\begin{array}{l}\text { B. mega- } \\
\text { terium }\end{array}$ & wood & - & - & - & - & - & - & $\begin{array}{c}183.33 \pm \\
23.57\end{array}$ & $\begin{array}{c}183.33 \pm \\
23.57\end{array}$ & $>1$ \\
\hline B. cereus & wood & - & - & - & $\begin{array}{c}75.00 \pm \\
9.64\end{array}$ & $\begin{array}{c}68.19 \pm \\
0.00\end{array}$ & 0.3457 & - & - & - \\
\hline B. pumilus & painting & - & - & - & $\begin{array}{c}116.67 \pm \\
57.70\end{array}$ & 0 & 0.0728 & $\begin{array}{c}93.333 \pm \\
11.55\end{array}$ & $\begin{array}{c}106.67 \pm \\
11.55\end{array}$ & 0.2301 \\
\hline $\begin{array}{l}\text { B. mega- } \\
\text { terium }\end{array}$ & textile & - & - & - & - & - & - & 0 & $\begin{array}{c}75.76 \pm \\
13.89\end{array}$ & $<0.05$ \\
\hline B. cereus & wooden & - & - & - & $\begin{array}{c}87.50 \pm \\
5.41\end{array}$ & $\begin{array}{c}75.00 \pm \\
0.00\end{array}$ & & 0 & $\begin{array}{c}76.67 \pm \\
4.71\end{array}$ & $<0.01$ \\
\hline
\end{tabular}

\section{Discussion}

This study was conducted to reveal the efficiency of Allium sativum hydro-alcoholic extract as an eco-friendly solution to combat fungi and bacteria involved in biodeterioration of cultural heritage buildings and objects. The bioevaluation of the proposed solution was performed on a significant collection of more than 200 biodeteriogenic microbial strains previously isolated from churches and objects from different Romanian counties and characterized by culture dependent and independent methods.

We demonstrated that the antimicrobial activity of A. satioum hydro-alcoholic extract against biodeteriogenic fungal and bacterial strains is associated with the presence of allicin and thiosulfinic compounds identified by UHPLC that, from over 100 biologically active compounds derived from garlic, are known for their broad spectrum of antifungal activity $[20,28]$. However, the antimicrobial activity was tested in most studies against plant, animal, and human pathogenic strains. Choo et al., in 2020 showed that allicin could serve as a potential alternative strategy effective against $A$. fumigatus, A. niger, A. versicolor, $A$. terreus and Candida spp. responsible for human infections in immunocompromised patients [29]. Allicin acts on the cell wall, causing pore formation and thus promoting the action of synthetic fungicides, such as flucytosine and amphotericin B [30]. Actually, allicin can disrupt the cell's electrochemical potential and thus induce apoptosis in yeasts [31]. In general, disintegration of cytoplasm, breakdown of the cell membrane and cell wall, and collapse of hyphae were observed when fungi were treated with allicin and garlic extract [32]. Other authors have revealed that allicin could alter RNA and lipid or acetylCoA formation [33,34]. It has been demonstrated that allicin exhibited antifungal activities in vitro and in vivo against common plant pathogenic fungi [35,36]. Allicin has been shown to exhibit broad-spectrum antimicrobial activity against multidrug-resistant Gram-positive bacteria (e.g., S. aureus strains) [37]. Other major chemical compounds identified in this study are reported as having antimicrobial activity although very few of them have been tested against biodeteriogenic fungi. A study conducted by [38] showed that stilbenoids (resveratrol and some of its derivatives) are very effective against phytopathogenic fungi such as A. flavus, P. italicum, A. terreus, and F. verticillioides and recommends them as food preservatives. Similarly, Oliveira et al., in 2015, proved that quercetin and rutin might act as enhancers of amphotericin B antifungal activity and reduced its cytotoxic effect against red blood cells [39]. Rutin acts as a pro-oxidant that induces ROS generation and subsequently causes cell membrane disruption and protein denaturation [40]. p-Coumaric 
acid can inhibit $F$. oxysporum and F. verticillioides at low MIC values (below $576 \mu \mathrm{g} / \mathrm{mL}$ ) but has no effect against P. brevicompactum, P. expansum, A. flavus, and A. fumigatus, which are frequently isolated from heritage buildings. Regarding the antibacterial activity of p-coumaric acid and its derivatives (caffeic acid, ferulic acid, and chlorogenic acid), a significant inhibitory potential was recorded at concentrations higher than $1 \mathrm{mg} / \mathrm{mL}$ when tested against bacterial strains such as S. aureus, S. epidermidis, S. agalactiae, or E. coli [41]. Although limited potential was described until now, some of the compounds from our garlic extract such as vanillin and p-coumaric acid might act as mycotoxin inhibitors [42], which is why such a research direction of should be addressed, taking into account the fact that many of the biodeteriogenic fungi can produce mycotoxins.

A. sativum extract can represent an eco-friendly solution to combat biodeteriogenic strains belonging to bacteria (Arthrobacter spp., Bacillus spp., Micrococcus spp., Paracoccus spp.) or fungi (Alternaria spp., Aspergillus spp., Penicillium spp., Phoma spp., Fusarium spp., Cladosporium spp.) recovered from a stonework surface [43]; Kutawa et al., in 2018, showed that ethanolic A. sativum extract is active on Fusarium spp. and Rhizopus spp. $(2.5 \mathrm{mg} / \mathrm{mL}$ and $5.0 \mathrm{mg} / \mathrm{mL}$ for Fusarium spp. and Rhizopus spp., respectively) [44]. Yetgin et al., in 2018, demonstrated that the antimicrobial activities of two samples of A. sativum alcoholic extracts from Turkey and China against seven genera of bacterial strains and C. albicans depended on the geographic origin of the plant [14].

The antimicrobial activity of $A$. sativum extract was also evaluated against $B$. subtilis, Micrococcus luteus, P. chrysogenum, and Aspergillus spp. strains isolated from colonized artworks in Italy, suggesting the possible use in the control of biodeterioration of cultural heritage, safe both for human health and the environment [45]. In Romania, until the present, the only antimicrobial activity that has been demonstrated is of the Ocimum basilicum and A. ursinum hydro-alcoholic extracts and essential oils against Aspergillus spp., Penicillium spp., and Mucor spp. recovered from paper artefacts [16,17].

Biofilm formation is one of the first steps involved in biodeterioration of historic monuments followed by secretion of different enzymes that affect the substrate [46], which is why the development of strategies to prevent the adhesion of biodeteriogenic microorganisms to the surface of the heritage objects is highly necessary. This study demonstrated that the most adherent biodeteriogenic fungal strains were isolated from textiles, followed by wooden and stone objects, and a significant inhibition of microbial adhesion was obtained in the presence of garlic extract. Many of the chemical compounds identified in the garlic extract, although not directly tested on biodeteriogenic microbial strains, have been described as having anti-adhesion activity. A study conducted by Deepika et al. in 2016 shows that rutin inhibits biofilm formation by P. aeruginosa, and its effect might be improved by combining it with small doses of gentamicin [47]. Moreover, gallic acid showed good inhibitory action both on growth and biofilm formation in the case of Gramnegative bacteria, Gram-positive bacteria [48], and C. albicans [49]. Similarly, p-coumaric acid and gallic acid are involved in decreasing the rate of $P$. fluorescence colonization on abiotic surfaces by reducing the expression level of $f l g A$ gene, which is responsible for flagella production [50]. Allicin is another compound that can exert anti-adhesion activity against a wide variety of microorganisms, including filamentous fungal species such as A. flavus, A. fumigatus, A. niger, A. terreus, and A. versicolor when administered in combination with various fungicides such as amphotericin B [29]. Allicin might also inhibit polysaccharide intercellular adhesins synthesis, which is required for the biofilm formation in S. epidermidis [51]. Moreover, it reduces exopolysaccharide production in $P$. aeruginosa and downregulates the expression of different virulence factors involved in quorum sensing, an intercellular communication mechanism involved in the regulation of biofilm development [52]. A study conducted by Girish et al. in 2019 presents a polymeric matrix functionalized with garlic extract as a strategy with high efficiency in penetrating and disrupting the methicillin-resistant $S$. aureus biofilms [53].

Deteriogenic fungal strains produced cellulase, esterase (34.21\% of each enzyme type), and organic acid (52.63\%). A reduction or inhibition of cellulose/organic acid/esterase 
production by $61.54 \% / 55 \% / 23.08 \%$ was observed for the analyzed fungal strains grown in the presence of garlic extract. The inhibitory action of $A$. satioum extract against enzyme production can be attributed to the presence of alliin, gamma-glutamyl-S-methyl cysteine, gamma-glutamyl-(S)-allyl cysteine, gamma-glutamyl-S-trans-propenyl cysteine, and allicin as the major antifungal components.

Microbial strains, due to their metabolic diversity, designed to ensure their survival in different environments, are the main responsible sources of heritage object deterioration. For the stone monuments, microorganisms are responsible for pigment production and structural damage due to their ability to penetrate the depth of the support. Moreover, some of them are able to produce organic and inorganic acids and to determine salt crystallization that, in the end, causes discoloration and erosion [54]. For wood and paper biodeterioration, lignocellulolytic microorganisms play the main role $[55,56]$, while in the case of man-made textiles, esterase-producing microbial strains can cause significant damage. Similarly, the deterioration of paintings is caused by a multitude of enzymes produced by biodeteriogenic microorganisms such as amylase, lipase/esterase, protease, and acids [52,55,56]. A study conducted by El Hassni et al. in 2021 showed that caffeic acid, p-coumaric acid, and ferulic acid have great inhibitory action on hydrolytic enzyme production by F. oxysporum [57]. The in vitro analysis indicated an inhibition rate of 63 to $98 \%$ for cellulase and 91 to $100 \%$ for pectinemethyl-esterase. Moreover, phenols from rice straw (mainly coumaric acid and ferulic acid) decreased up to $23 \%$ of the cellulase activity of T. reesei [58]. Abu-Taleb and his colleagues proved that flavonoid subfractions from Rumez vesicarius and Ziziphus spina-christi ethanolic extracts (containing rutin, quercitin, apigenin, and kaempherol) inhibit both spore production and cellulase activity of F. solani and Drechslera biseptata fungal strains [59].

\section{Materials and Methods}

\subsection{Preparation of Plant Extract}

For ultrasound-assisted extraction, a sonication water bath with frequency between 20 and $2000 \mathrm{kHz}$ was used, allowing the cell lysis. Five grams of grounded plant material obtained from Romanian organic agriculture were mixed with $25 \mathrm{~mL}$ of ethanol 50\%. The obtained extract was filtered and brought to the mark in a $50 \mathrm{~mL}$ volumetric flask.

\subsection{The Total Phenolic Content (TPC) Assay}

TPC content was determined by the Folin-Ciocalteu method [60]. Briefly, an aliquot was mixed with $100 \mu \mathrm{L}$ Folin-Ciocalteu reagent, $900 \mu \mathrm{L}$ distilled water, and $1000 \mu \mathrm{L}$ of saturated sodium carbonate. The tubes were vortexed for $15 \mathrm{~s}$ and allowed to stand in the dark for $60 \mathrm{~min}$ for color development. Absorbance was then measured at $765 \mathrm{~nm}$ using a FlexStation 3 UV-VIS (Molecular Devices Company, Sunnyvale, CA, USA) spectrophotometer. A standard curve was prepared by using different concentrations of gallic acid in the same condition with samples $\left(\mathrm{R}^{2}=0.9972\right)$. TPC content was expressed as milligram gallic acid equivalent/g plant material (mg GAE/g). Analyses were performed in triplicate.

\subsection{The Total Flavonoid Content Assay}

Flavonoid content was assessed through the $\mathrm{AlCl}_{3}$ method [61]. Briefly, $0.1 \mathrm{~mL}$ sample/standard solution was mixed with $0.1 \mathrm{~mL}$ sodium acetate $10 \%$ and $0.12 \mathrm{~mL} \mathrm{AlCl}_{3}$ $2.5 \%$, with the final volume being adjusted to $1 \mathrm{~mL}$ with ethanol $50 \%$. The samples were then vortexed and incubated in the dark for $45 \mathrm{~min}$. The absorbances were measured at $\lambda=430 \mathrm{~nm}$. A standard curve was prepared by using different concentrations of quercetin $\left(\mathrm{R}^{2}=0.9956\right)$. Total flavonoid content was expressed as milligram quercetin equivalent/g dry leaves (mg QE/g DL). Analyses were performed in triplicate. 


\subsection{Total Thiosulfinate Content Assay}

A spectrophotometric method based on the reaction of DTNB was used to measure the thiosulfinate content according to [22,62]. An aliquot of $625 \mu \mathrm{L}$ of $0.8 \mathrm{mM}$ cysteine solution was added to $375 \mu \mathrm{L}$ of garlic extract or a similar aliquot of distilled water (blank). The samples were kept for $10 \mathrm{~min}$ at room temperature, and an aliquot of $200 \mu \mathrm{L}$ of garlic/cysteine solution or water/cysteine solution was added to $800 \mu \mathrm{L}$ of $200 \mu \mathrm{M}$ DTNB, which was prepared in $50 \mathrm{mM}$ HEPES buffer. After shaking, test samples were left for $10 \mathrm{~min}$ to allow for color development. Absorbance was measured at $412 \mathrm{~nm}$, and the thiosulfinate concentrations were calculated, taking into account $\varepsilon=14,150 \mathrm{M}^{-1} \times \mathrm{cm}^{-1}$. Total tiosulfinate content was expressed as $\mu \mathrm{M}$ allicin equivalent/g plant material (mg QA/g). Analyses were performed in triplicate.

\subsection{Characterization of the Extract by UHPLC-MS/MS}

Polyphenolic compound quantification and qualitative identification of thiosulfinate compounds were performed using a high-resolution Q Exactive mass spectrometer ${ }^{\mathrm{TM}}$ Focus Hybrid Quadrupole-OrbiTrap (Thermo Fisher Scientific) equipped with HESI, coupled to a high-performance liquid chromatograph UltiMate 3000 UHPLC (ThermoFisher Scientific). Chromatographic separation was performed on a Kinetex ${ }^{\circledR} \mathrm{C} 18$ column $(100 \times 2.1 \mathrm{~mm}, 1.7 \mu \mathrm{m}$ particle diameter $)$ at $30^{\circ} \mathrm{C}$. Mobile phase: A-water with $0.1 \%$ formic acid and $\mathrm{B}-$ methanol with $0.1 \%$ formic acid, elution in gradient at a flow rate between 0.3 and $0.4 \mathrm{~mL} / \mathrm{min}$. For polyphenolic compound quantification, including phenolic acids, flavonoids, stilbenoids (t-resveratrol), and sesquiterpenoid hormones (abscisic acid), the mass spectra were recorded in negative ionization mode, in a range between $\mathrm{m} / \mathrm{z}$ 100 and 800, at a resolution of 70,000, while for thiosulfinate compounds, the mass spectra were recorded in positive ionization mode. Nitrogen was used as collision gas and auxiliary gas at a flow rate of 11 and 48 arbitrary units, respectively. The applied voltage was $2.5 \mathrm{kV}$, and the capillary temperature was $320^{\circ} \mathrm{C}$. The energy of the collision cell varied between 30 and $60 \mathrm{eV}$. For polyphenolic compound quantification, calibration was performed in the concentration range between 0 and $1000 \mu \mathrm{g} / \mathrm{L}$ for each of the phenolic acids and flavonoids by serial dilution with methanol of the standard mixture of concentration $10 \mathrm{mg} / \mathrm{L}$ [63]. The data were purchased and processed using the Xcalibur software package (Version 4.1). ChemSpider reference spectral database (www.chemspider.com, accessed on 22 March 2021) was used as a reference library to identify thiosulfinate compounds of interest.

\subsection{Antioxidant Activity Assay}

\subsubsection{DPPH Assay}

It was performed according to the method of [64] with some slight changes. The reaction mixture consisted of adding $100 \mu \mathrm{L}$ of sample/standard and $100 \mu \mathrm{L}$ of $0.3 \mathrm{mM}$ DPPH radical solution in $50 \%$ ethanol. The absorbance was measured at $\lambda=517 \mathrm{~nm}$ after 30 min of incubation in the dark using a UV-VIS spectrophotometer. The concentrations used for the Trolox calibration curve were in the range of 5-80 $\mu \mathrm{M}\left(\mathrm{R}^{2}=0.9988\right)$.

\subsubsection{CUPRAC Method}

Copper ion reduction was performed according to a method adapted from [65], as follows: $20 \mu \mathrm{L}$ of sample/standard solutions were mixed with $60 \mu \mathrm{L} \mathrm{CuSO}_{4}(5 \mathrm{mM})$, neocuproine $60 \mu \mathrm{L}(3.75 \mathrm{mM})$, and distilled water $(560 \mu \mathrm{L})$, reaching a final volume of $700 \mu \mathrm{L}$. After $30 \mathrm{~min}$, the absorbance was measured at $450 \mathrm{~nm}$. The standard Trolox solutions required for the calibration curve were between 1 and $0 \mathrm{mM}\left(R^{2}=0.9952\right)$.

\subsubsection{FRAP Assay}

The antioxidant power determination of iron reduction was performed by the method described by Benzie and Strain in 1999 [66], with some modification. The following solutions were prepared: $300 \mathrm{mM}$ acetate buffer (pH 3.6), $10 \mathrm{mM}$ TPTZ stock solution in $40 \mathrm{mM} \mathrm{HCl}$, and $20 \mathrm{mM} \mathrm{FeCl}_{3}$ solution in distilled water. The FRAP reagent was obtained 
by mixing $300 \mathrm{mM}$ acetic acid-sodium acetate buffer (pH 3.6) with $10 \mathrm{mM}$ TPTZ solution and $20 \mathrm{mM} \mathrm{FeCl}$ solution (10:1:1). The FRAP reagent was kept on an incubator at $37^{\circ} \mathrm{C}$ until the time of analysis. To $10 \mu \mathrm{L}$ sample/standard solution, $190 \mu \mathrm{L}$ FRAP reagent was added, and the mixture was incubated for $30 \mathrm{~min}$ at $37^{\circ} \mathrm{C}$. After incubation, the absorbance at $\lambda=593 \mathrm{~nm}$ was read. The calibration curve was performed for the concentration range $0-250 \mu \mathrm{M}$ Trolox $/ \mathrm{mL}\left(\mathrm{R}^{2}=0.9978\right)$.

\subsection{Qualitative Screening of the Antimicrobial Activity of the Tested Plant Extract}

The qualitative screening of the antimicrobial activity was performed by an adapted diffusion method on Sabouraud agar (SDA) medium inoculated with standard fungal cell suspensions prepared from the following stains: Penicillium chrysogenum, P. corylophylum, $P$. expansum, P. digitatum, Aspergillus niger, A. flavus, A. clavatus, A. nidulans, A. ochraceus, A. versicolor, A. ustus, A. sydowi, Rhizopus oryzae, T. orientale, Byssochlamys spectabilis, Alternaria alternata, Purpureocillium lilacinum, Fusarium proliferatum, F. cerealis culmorum group, and Cladosporium spp. The Mueller-Hinton (MH) medium was used to assess the antibacterial activity against the following bacterial strains: Bacillus pumilus, B. megaterium, B. cereus, B. mojavensis, B. atrophaeus, B. subtilis, B. endophyticus, B. thuringiensis, A. aurascens, A. globiformis, A. bergeri, P. abietaniphila, $P$. koreensis, and $R$. erythropolis species. The strains were isolated previously from heritage churches, objects, and from two museum collections in Romania during 2018 and 2019 [10]. Subsequently, $10 \mu \mathrm{L}$ of hydro-alcoholic extract $(100 \mathrm{mg} / \mathrm{mL})$, as already presented in Section 2.1, was prepared in sterile water, and solvent control (ethanol 50\%) was spotted over it. The plates were incubated for 5-7 days at room temperature for $24 \mathrm{~h}$ at $37^{\circ} \mathrm{C}$; then, the growth inhibition diameter zone was measured and the values were converted into arbitrary units using the following convention: 0 value for no inhibition zone, 1 value for a growth inhibition diameter zone up to $10 \mathrm{~mm}$, and 2 value for a growth inhibition diameter zone of $11-20 \mathrm{~mm}$.

\subsection{Quantitative Evaluation of the Antimicrobial Activity of the Plant Extract}

The quantitative evaluation of the antifungal activity was performed in RPMI (Roswell Park Memorial Institute) 1640/MH Broth medium using the microdilution method in 96 multi-well plates [67]. The serial twofold microdilutions of the compounds were achieved in $100 \mu \mathrm{L}$ of RPMI 1640/MH broth medium seeded with the standard fungal/bacterial inoculum of $0.4-5 \times 10^{4} \mathrm{CFU} / \mathrm{mL}$. After incubation for 5-7 days at room temperature for $24 \mathrm{~h}$ at $37^{\circ} \mathrm{C}$, the minimum inhibitory concentration (MIC) values were established in correspondence to the lowest concentration, at which the tested plant extract inhibited the growth of the microbial cultures. The final results were calculated and graphically expressed after the solvent (ethanol 50\% diluted in the same manner as the extract) inhibitory effect was eliminated.

\subsection{The Influence of A. sativum Extract on the Microbial Adherence Capacity to the Inert Surface}

The influence on the ability of microbial adherence to the inert substratum (96-well plate, untreated polystyrene) was measured after running the quantitative analysis of the antimicrobial activity by evaluating the biofilm biomass, after fixation with methanol and crystal violet staining. The optical density of the biological material resuspended in acetic acid 33\% was determined by reading the absorbance at $490 \mathrm{~nm}$. Negative, positive, and solvent controls were used. The positive control highlights the sterile working conditions, where no microbial cell has adhered to the substrate. Positive controls are represented by the natural adhesion of untreated microbial strains. The solvent control concentration was similar with that of ethanol. The experiment was performed in triplicate. The formula used for the evaluation of the microbial adherence capacity was

$$
\mathrm{IIBG} \%=100-(\text { Ae-s } \times 100) / \mathrm{Ac}
$$

where Ae-s = the absorbance of the biofilm formed and treated with extract/solvent, and $A c=$ the absorbance of the biofilm formed untreated. 


\subsection{The Influence of A. satioum Hydro-Alcoholic Extract on the Production of Microbial Enzymes and Organic Acids Involved in Biodeterioration}

Microbial strains treated with subinhibitory concentration of alcoholic extract (MIC/4) were evaluated for their capacity to release different biodegradative enzymes and organic acids. In this purpose, different culture media were spotted with $10 \mu \mathrm{L}$ suspension adjusted to $1 \mathrm{McFarland}$ prepared from each microbial strain (untreated culture, serving as growth control and treated with A. sativum) and then incubated at $26-28^{\circ} \mathrm{C}$ for $5-8$ days.

Cellulase production was examined on agar plates containing cellulose (CMC, $5 \mathrm{~g}$, Avicel), yeast extract $(1 \mathrm{~g})$, Congo red $0.05 \mathrm{~g} / 100 \mathrm{~mL}$, agar $15 \mathrm{~g}$, and distilled water $1000 \mathrm{~mL}$ at $\mathrm{pH}$ 7.0. A clear zone around the microbial colonies indicates cellulose hydrolysis. Phenoloxidase activity was determined on agar plates containing malt extract (15 g), agar $(20 \mathrm{~g}), 100 \mathrm{~mL}$ tannic acid water solution $(0.08 \%)$ (sterilized by filtration and added after autoclaving), and distilled water up to $1000 \mathrm{~mL}$ at $\mathrm{pH} 7.0$ [68]. For the esterase production, agar plates containing peptone $(20 \mathrm{~g}), \mathrm{NaCl}(10 \mathrm{~g}), \mathrm{CaCl}(0.2 \mathrm{~g})$, Tween $20(20 \mathrm{~mL})$ (added after sterilization), agar (30 g), and distilled water $1000 \mathrm{~mL}$ at pH 5.4 [69] were used. For the acid production, agar plates containing sodium nitrate $(2 \mathrm{~g})$, dipotassium phosphate $(1 \mathrm{~g})$, magnesium sulphate $(0.5 \mathrm{~g})$, potassium chloride $(0.5 \mathrm{~g})$, ferrous sulphate $(0.01 \mathrm{~g})$, glucose $(10 \mathrm{~g})$, phenol red $(0.003 \mathrm{~g})$, agar $(20 \mathrm{~g})$, and distilled water $1000 \mathrm{~mL}$ at $\mathrm{pH} 7.0$ [70] were used.

The inhibitory activity was semi-quantitatively evaluated by measuring the ratio of the colony diameter $(\mathrm{C})$ to the diameter of the specific inhibition zone occurring around the colony (D) (e.g., clear zone for cellulase activity, a precipitation zone for phenoloxidase, a brown zone for esterase, and a change of color from red to yellow in the area in the immediate vicinity of the culture spot for organic acids).

Finally, the influence of $A$. sativum extract and solvent control (the same ethanol concentration as the extract used) on cellulose, esterase, phenoloxidase, and organic acid production was quantified by the following equation:

$$
\text { Inhibition }(\%)=\frac{D 2-C 2}{D 1-C 1} \times 100,
$$

where $\mathrm{C} 1$ - colony diameter of control strain, $\mathrm{D} 1$-inhibitory effect zone diameter of strain control, C2 - colony diameter of treated strain, and D2-inhibitory effect zone diameter of treated strain.

\subsection{Statistical Analysis}

Data were expressed as means \pm SD determined by triplicate analysis. The statistical analysis was conducted using GraphPad Prism 9. Data were analyzed using unpaired $t$-test with Welch correction of multiple comparisons for antibiofilm activity and enzymatic inhibition activity, and no correction for multiple comparisons in the case of antimicrobial activity. The level of significance was set to $p<0.05$.

\section{Conclusions}

To the best of our knowledge, this is the first study conducted to demonstrate the efficiency of the garlic extract against a significant number of fungal and bacterial biodeteriogenic strains isolated from different surfaces of cultural heritage objects and buildings from outdoor and indoor environments and to assess its inhibitory activity not only on microbial growth, but also on biofilm development and production of different factors involved in biodeterioration. The study design also allowed us to stratify the efficiency of the garlic extract depending on the genera and species, but also on the type of material/surface. The main compounds identified in the garlic extract were thiosulfinate, flavonoids, and polyphenols. The most susceptible species were B. spectabilis, Cladosporium spp., and T. orientale. From the species of the most frequently isolated genera (Penicillium spp. and Aspergillus spp.), the A. sativum plant extract demonstrated the highest efficiency against the $A$. versicolor, A. ochraceus, P. expansum, and A. niger strains. Fungi isolated from 
paintings and paper as well as bacteria from wood, paper, and textiles responded better to the garlic extract treatments, as revealed by the low MIC values. The tested extract inhibited the adherence capacity and the production of biodeteriogenic products, such as cellulase, organic acids, and esterase. The results of this study show the great potential of the tested extract on the conservation and, thus, on the safeguarding of monuments by maintaining the carpentry and masonry in a stage that allows for the transmission of this tangible heritage to future generations.

Supplementary Materials: The following are available online. Figure S1. Allium sativum inhibitory activity against fungi and bacteria (in percent) expression by arbitrary units of inhibition zone diameter. Figure S2. Allium sativum inhibitory activity against fungi and bacteria (in percent) expressed by arbitrary units of growth inhibition zones diameter.

Author Contributions: Conceptualization, V.M.C., I.G., O.C. and M.C.C.; methodology, V.M.C., I.G., I.C.M. and E.I.G.; software, I.C.M.; validation, V.M.C., I.G., I.C.M., E.I.G., O.C., M.I.M. and M.C.C.; formal analysis, V.M.C., I.G., I.C.M., E.I.G. and O.C.; investigation, V.M.C., I.G., I.C.M. and E.I.G.; resources, I.G., M.C.C. and I.C.M.; data curation, V.M.C. and I.G.; writing-original draft preparation, V.M.C. and I.G.; writing-review and editing, M.I.M., M.C.C., O.C. and I.C.M.; visualization, V.M.C., I.G., O.C., I.C.M., E.I.G., O.C., M.I.M. and M.C.C.; supervision, M.C.C., O.C. and I.G.; project administration, I.G. and M.C.C.; funding acquisition, I.G. and M.C.C. All authors have read and agreed to the published version of the manuscript.

Funding: This research was funded by CNFIS-FDI, grant number 2021-0405.

Conflicts of Interest: The authors declare no conflict of interest.

Sample Availability: Samples of the compounds are available from the authors.

\section{References}

1. Rădulescu, H.C.; Perdum, E.; Mitran, C.E.; Dincă, L.C.; Lazăr, V. Biodeterioration capacity of a microfungal species isolated from textile cultural heritage items on contemporary wool materials. Publ. House Rom. Acad. Ser. B 2018, 20, 167-171.

2. Sterflinger, K. Fungi: Their role in deterioration of cultural heritage. Fungal Biol. Rev. 2010, 24, 47-55. [CrossRef]

3. Savković, Ž.; Stupar, M.; Unković, N.; Knežević, A.; Vukojević, J.; Grbić, M.L. Fungal Deterioration of Cultural Heritage Objects. In Biodegradation; IntechOpen: London, UK, 2021.

4. Moza, M.I.; Mironescu, M.; Georgescu, C.; Florea, A.; Bucşa, L. Isolation and characterisation of moulds degrading mural paintings. Ann. Rscb 2012, 17, 136-142.

5. Lupan, I.; Ianc, M.; Kelemen, B.; Carpa, R.; Rosca-Casian, O.; Chiriac, M.; Popescu, O. New and old microbial communities colonizing a seventeenth-century wooden church. Folia Microbiol. 2014, 59, 45-51. [CrossRef]

6. IIies, D.; Onet, A.; Wendt, J.A.; Ilieş, M.; Timar, A.; Ilies, A.; Baias, Ş.; Herman, G. Study on microbial and fungal contamination of air and wooden surfaces inside of a historical Church from Romania. J. Environ. Biol. 2018, 39, 980-984.

7. Rădulescu, H.C.; Gheorghe, I.; Gradisteanu, G.; Ispas, A.; Popescu, C.; Roşu, G.; Chifiriuc, M.C.; Lazăr, V. Molecular characterization based on Internal Transcribed Spacer (ITS) marker sequence of fungal strains isolated from heritage ethnographic textiles. Rom. Biotechnol. Lett. 2019, 24, 906-912. [CrossRef]

8. Ilies, D.C.; Oneț, A.; Grigore, H.; Liliana, I.; Alexandru, I.; Ligia, B.; Ovidiu, G.; Florin, M.; Ștefan, B.; Tudor, C. Exploring the indoor environment of heritage buildings and its role in the conservation of valuable objects. Environ. Eng. Manag. J. EEMJ 2019, 18, 2579-2586. [CrossRef]

9. Sirghi, A.C.; Gheorghe, I.; Sarbu, I.; Marutescu, L.; Stoian, G.; Zhiyong, Z.; Chifiriuc, M.C. Identification of fungal strains isolated from buildings of cultural importance in Romania and antagonistic relationships amongst them. Rom. Biotechnol. Lett. 2018, 24, 1008-1014. [CrossRef]

10. Gheorghe, I.; Sârbu, I.; Pecete, I.; Blăjan, I.; Balotescu, I. Multi-level characterization of microbial consortia involved in the biodeterioration of wooden and stone romanian heritage churches. Conserv. Sci. Cult. Herit. 2020, 20, $289-308$.

11. Palla, F.; Bruno, M.; Mercurio, F.; Tantillo, A.; Rotolo, V. Essential oils as natural biocides in conservation of cultural heritage. Molecules 2020, 25, 730. [CrossRef]

12. Rosado, T.; Silva, M.; Dias, L.; Candeias, A.; Gil, M.; Mirão, J.; Pestana, J.; Caldeira, A.T. Microorganisms and the integrated conservation-intervention process of the renaissance mural paintings from Casas Pintadas in Évora-Know to act, act to preserve. J. King Saud Univ. Sci. 2017, 29, 478-486. [CrossRef]

13. Gheorghe, I.; Avram, I.; Matis Corbu, V.; Măruţescu, L.; Popa, M.; Balotescu, I.; Blăjan, I.; Mateescu, V.; Zaharia, D.; Dumbravă, A.S. In vitro evaluation of $\mathrm{MgB} 2$ powders as novel tools to fight fungal biodeterioration of heritage buildings and objects. Front. Mater. 2021, 7, 458. [CrossRef] 
14. Yetgin, A.; Canlı, K.; Altuner, E.M. Comparison of antimicrobial activity of Allium sativum cloves from China and Taşköprü, Turkey. Adv. Pharmacol. Sci. 2018, 2018, 9302840.

15. Grumezescu, A.M.; Andronescu, E.; Holban, A.M.; Ficai, A.; Ficai, D.; Voicu, G.; Grumezescu, V.; Balaure, P.C.; Chifiriuc, C.M. Water dispersible cross-linked magnetic chitosan beads for increasing the antimicrobial efficiency of aminoglycoside antibiotics. Int. J. Pharm. 2013, 454, 233-240. [CrossRef]

16. Fierascu, I.; Dima, R.; Fierascu, R.C. Natural Extracts for preventing Artefacts Biodeterioration. In Proceedings of the International Conference on Cultural Heritage and New Technologies Vienna, Vienna, Austria, 5-7 November 2012.

17. Fierascu, I.; Ion, R.M.; Radu, M.; Bunghez, I.; Avramescu, S.; Fierascu, R. Comparative study of antifungal effect of natural extracts and essential oils of Ocimum basilicum on selected artefacts. Rev. Roum. Chim. 2014, 59, 207-211.

18. Wu, X.; Santos, R.R.; Fink-Gremmels, J. Analyzing the antibacterial effects of food ingredients: Model experiments with allicin and garlic extracts on biofilm formation and viability of Staphylococcus epidermidis. Food Sci. Nutr. 2015, 3, 158-168. [CrossRef] [PubMed]

19. Woods-Panzaru, S.; Nelson, D.; McCollum, G.; Ballard, L.M.; Millar, B.C.; Maeda, Y.; Goldsmith, C.E.; Rooney, P.J.; Loughrey, A.; Rao, J.R. An examination of antibacterial and antifungal properties of constituents described in traditional Ulster cures and remedies. Ulst. Med. J. 2009, 78, 13.

20. Khan, S.; Imran, M.; Imran, M.; Pindari, N. Antimicrobial activity of various ethanolic plant extracts against pathogenic multi drug resistant Candida spp. Bioinformation 2017, 13, 67. [CrossRef] [PubMed]

21. Santos, D.I.; Neiva Correia, M.J.; Mateus, M.M.; Saraiva, J.A.; Vicente, A.A.; Moldão, M. Fourier transform infrared (FT-IR) spectroscopy as a possible rapid tool to evaluate abiotic stress effects on pineapple by-products. Appl. Sci. 2019, 9, 4141. [CrossRef]

22. Gonzalez, R.E.; Soto, V.C.; Sance, M.M.; Camargo, A.B.; Galmarini, C.R. Variability of solids, organosulfur compounds, pungency and health-enhancing traits in garlic (Allium sativum L.) cultivars belonging to different ecophysiological groups. J. Agric. Food Chem. 2009, 57, 10282-10288. [CrossRef] [PubMed]

23. Martínez, G.; Regente, M.; Jacobi, S.; Del Rio, M.; Pinedo, M.; de la Canal, L. Chlorogenic acid is a fungicide active against phytopathogenic fungi. Pestic. Biochem. Physiol. 2017, 140, 30-35. [CrossRef] [PubMed]

24. Zhu, C.; Lei, M.; Andargie, M.; Zeng, J.; Li, J. Antifungal activity and mechanism of action of tannic acid against Penicillium digitatum. Physiol. Mol. Plant Pathol. 2019, 107, 46-50. [CrossRef]

25. Miron, T.; Rabinkov, A.; Mirelman, D.; Wilchek, M.; Weiner, L. The mode of action of allicin: Its ready permeability through phospholipid membranes may contribute to its biological activity. Biochim. Biophys. BBA Biomembr. 2000, 1463, 20-30. [CrossRef]

26. Gruhlke, M.C.; Hemmis, B.; Noll, U.; Wagner, R.; Lühring, H.; Slusarenko, A.J. The defense substance allicin from garlic permeabilizes membranes of Beta vulgaris, Rhoeo discolor, Chara corallina and artificial lipid bilayers. Biochim. Biophys. Acta BBA Gen. Subj. 2015, 1850, 602-611. [CrossRef] [PubMed]

27. Leontiev, R.; Hohaus, N.; Jacob, C.; Gruhlke, M.C.; Slusarenko, A.J. A comparison of the antibacterial and antifungal activities of thiosulfinate analogues of allicin. Sci. Rep. 2018, 8, 6763. [CrossRef]

28. Negri, M.; Salci, T.P.; Shinobu-Mesquita, C.S.; Capoci, I.R.; Svidzinski, T.I.; Kioshima, E.S. Early state research on antifungal natural products. Molecules 2014, 19, 2925-2956. [CrossRef]

29. Choo, S.; Chong, P.; Tay, S.; Wong, E.; Madhavan, P.; Yong, P. Inhibition of sessile and biofilm growth in various Aspergillus species by allicin associated with disruption to structural changes in cell wall. Int. J. Infect. Dis. 2020, 101, 71. [CrossRef]

30. Kim, Y.-S.; Kim, K.S.; Han, I.; Kim, M.-H.; Jung, M.H.; Park, H.-K. Quantitative and qualitative analysis of the antifungal activity of allicin alone and in combination with antifungal drugs. PLoS ONE 2012, 7, e38242. [CrossRef]

31. Gruhlke, M.C.; Portz, D.; Stitz, M.; Anwar, A.; Schneider, T.; Jacob, C.; Schlaich, N.L.; Slusarenko, A.J. Allicin disrupts the cell's electrochemical potential and induces apoptosis in yeast. Free Radic. Biol. Med. 2010, 49, 1916-1924. [CrossRef]

32. Aala, F.; Yusuf, U.K.; Nulit, R.; Rezaie, S. Inhibitory effect of allicin and garlic extracts on growth of cultured hyphae. Iran. J. Basic Med. Sci. 2014, 17, 150.

33. Salehi, B.; Zucca, P.; Orhan, I.E.; Azzini, E.; Adetunji, C.O.; Mohammed, S.A.; Banerjee, S.K.; Sharopov, F.; Rigano, D.; Sharifi-Rad, J. Allicin and health: A comprehensive review. Trends Food Sci. Technol. 2019, 86, 502-516. [CrossRef]

34. Rahman, M.S. Allicin and other functional active components in garlic: Health benefits and bioavailability. Int. J. Food Prop. 2007, 10, 245-268. [CrossRef]

35. Sarfraz, M.; Nasim, M.J.; Jacob, C.; Gruhlke, M.C. Efficacy of allicin against plant pathogenic fungi and unveiling the underlying mode of action employing yeast based chemogenetic profiling approach. Appl. Sci. 2020, 10, 2563. [CrossRef]

36. Curtis, H.; Noll, U.; Störmann, J.; Slusarenko, A.J. Broad-spectrum activity of the volatile phytoanticipin allicin in extracts of garlic (Allium sativum L.) against plant pathogenic bacteria, fungi and Oomycetes. Physiol. Mol. Plant Pathol. 2004, 65, 79-89. [CrossRef]

37. Getti, G.; Poole, P. Allicin causes fragmentation of the peptidoglycan coat in Staphylococcus aureus by effecting synthesis and aiding hydrolysis: A determination by MALDI-TOF mass spectrometry on whole cells. J. Med. Microbiol. 2019, 68, 667-677. [CrossRef] [PubMed]

38. Mattio, L.; Catinella, G.; Iriti, M.; Vallone, L. Inhibitory activity of stilbenes against filamentous fungi. Ital. J. Food Saf. 2021, 10, 8461. [CrossRef] [PubMed]

39. Oliveira, V.; Carraro, E.; Auler, M.E.; Khalil, N.M. Quercetin and rutin as potential agents antifungal against Cryptococcus spp. Braz. J. Biol. 2016, 76, 1029-1034. [CrossRef] 
40. Lee, W.; Woo, E.R.; Lee, D.G. Phytol has antibacterial property by inducing oxidative stress response in Pseudomonas aeruginosa. Free Radic. Res. 2016, 50, 1309-1318. [CrossRef]

41. Pei, K.; Ou, J.; Huang, J.; Ou, S. p-Coumaric acid and its conjugates: Dietary sources, pharmacokinetic properties and biological activities. J. Sci. Food Agric. 2016, 96, 2952-2962. [CrossRef]

42. Zabka, M.; Pavela, R. Antifungal efficacy of some natural phenolic compounds against significant pathogenic and toxinogenic filamentous fungi. Chemosphere 2013, 93, 1051-1056. [CrossRef]

43. Palla, F.; Rotolo, V.; Giordano, A. Biotechnology a Source of Knowledge in Agreement with Green Strategies for the Conservation of Cultural Assets. Conserv. Sci. Cult. Herit. 2019, 19, 69-80.

44. Kutawa, A.B.; Danladi, M.D.; Haruna, A. Regular article antifungal activity of garlic (Allium sativum) extract on some selected fungi. J. Med. Herbs Ethnomed. 2018, 4, 12-14.

45. Rotolo, V.; Barresi, G.; Di Carlo, E.; Giordano, A.; Lombardo, G.; Crimi, E.; Costa, E.; Bruno, M.; Palla, F. Plant extracts as green potential strategies to control the biodeterioration of cultural heritage. Int. J. Conserv. Sci. 2016, 839-846.

46. Dakal, T.C.; Cameotra, S.S. Microbially induced deterioration of architectural heritages: Routes and mechanisms involved. Environ. Sci. Eur. 2012, 24, 36. [CrossRef]

47. Deepika, M.S.; Thangam, R.; Sakthidhasan, P.; Arun, S.; Sivasubramanian, S.; Thirumurugan, R. Combined effect of a natural flavonoid rutin from Citrus sinensis and conventional antibiotic gentamicin on Pseudomonas aeruginosa biofilm formation. Food Control 2018, 90, 282-294. [CrossRef]

48. Shao, D.; Li, J.; Li, J.; Tang, R.; Liu, L.; Shi, J.; Huang, Q.; Yang, H. Inhibition of gallic acid on the growth and biofilm formation of Escherichia coli and Streptococcus mutans. J. Food Sci. 2015, 80, M1299-M1305. [CrossRef]

49. Teodoro, G.R.; Gontijo, A.V.; Salvador, M.J.; Tanaka, M.H.; Brighenti, F.L.; Delbem, A.C.; Delbem, Á.C.; Koga-Ito, C.Y. Effects of acetone fraction from Buchenavia tomentosa aqueous extract and gallic acid on Candida albicans biofilms and virulence factors. Front. Microbiol. 2018, 9, 647. [CrossRef] [PubMed]

50. Myszka, K.; Schmidt, M.T.; Białas, W.; Olkowicz, M.; Leja, K.; Czaczyk, K. Role of gallic and p-coumaric acids in the AHLdependent expression of flgA gene and in the process of biofilm formation in food-associated Pseudomonas fluorescens KM120. J. Sci. Food Agric. 2016, 96, 4037-4047. [CrossRef] [PubMed]

51. Cruz-Villalón, G.; Pérez-Giraldo, C. Effect of allicin on the production of polysaccharide intercellular adhesin in Staphylococcus epidermidis. J. Appl. Microbiol. 2011, 110, 723-728. [CrossRef]

52. Lihua, L.; Jianhui, W.; Jialin, Y.; Yayin, L.; Guanxin, L. Effects of allicin on the formation of Pseudomonas aeruginosa biofilm and the production of quorum-sensing controlled virulence factors. Pol. J. Microbiol. 2013, 62, 243. [CrossRef] [PubMed]

53. Girish, V.M.; Liang, H.; Aguilan, J.T.; Nosanchuk, J.D.; Friedman, J.M.; Nacharaju, P. Anti-biofilm activity of garlic extract loaded nanoparticles. Nanomed. Nanotechnol. Biol. Med. 2019, 20, 102009. [CrossRef]

54. Mazzoli, R.; Giuffrida, M.G.; Pessione, E. Back to the past: "Find the guilty bug-Microorganisms involved in the biodeterioration of archeological and historical artifacts". Appl. Microbiol. Biotechnol. 2018, 102, 6393-6407. [CrossRef] [PubMed]

55. Cappitelli, F.; Pasquariello, G.; Tarsitani, G.; Sorlini, C. Scripta manent? Assessing microbial risk to paper heritage. Trends Microbiol. 2010, 18, 538-542. [CrossRef] [PubMed]

56. Singh, A.P. A review of microbial decay types found in wooden objects of cultural heritage recovered from buried and waterlogged environments. J. Cult. Herit. 2012, 13, S16-S20. [CrossRef]

57. El Hassni, M.; Laadouzaa, H.; El Hadrami, A.; Dihazi, A.; Rakibi, Y.; Lemjiber, N.; Naamani, K. An in vitro evaluation of the effect of hydroxycinnamic acids on the growth and hydrolytic enzyme production in Fusarium oxysporum f. sp. albedinis. Arch. Phytopathol. Plant Prot. 2021, 54, 1553-1567. [CrossRef]

58. Zheng, W.; Zheng, Q.; Xue, Y.; Hu, J.; Gao, M.-T. Influence of rice straw polyphenols on cellulase production by Trichoderma reesei. J. Biosci. Bioeng. 2017, 123, 731-738. [CrossRef]

59. Abu-Taleb, A.M.; El-Deeb, K.; Al-Otibi, F.O. Assessment of antifungal activity of Rumex vesicarius L. and Ziziphus spina-christi (L.) Willd. extracts against two phytopathogenic fungi. Afr. J. Microbiol. Res. 2011, 5, 1001-1011. [CrossRef]

60. Singleton, V.L.; Orthofer, R.; Lamuela-Raventós, R.M. Analysis of total phenols and other oxidation substrates and antioxidants by means of folin-ciocalteu reagent. Methods Enzymol. 1999, 299, 152-178.

61. Formagio, A.S.; Kassuya, C.A.; Neto, F.F.; Volobuff, C.R.; Iriguchi, E.K.; do C Vieira, M.; Foglio, M.A. The flavonoid content and antiproliferative, hypoglycaemic, anti-inflammatory and free radical scavenging activities of Annona dioica St. Hill. BMC Complement. Altern. Med. 2013, 13, 14. [CrossRef]

62. Mansor, N.; Herng, H.J.; Samsudin, S.J.; Sufian, S.; Uemura, Y. Quantification and characterization of allicin in garlic extract. J. Med. Bioeng. 2016, 5, 24-27. [CrossRef]

63. Marinas, I.C.; Oprea, E.; Geana, E.-I.; Tutunaru, O.; Pircalabioru, G.G.; Zgura, I.; Chifiriuc, M.C. Valorization of Gleditsia triacanthos Invasive Plant Cellulose Microfibers and Phenolic Compounds for Obtaining Multi-Functional Wound Dressings with Antimicrobial and Antioxidant Properties. Int. J. Mol. Sci. 2021, 22, 33. [CrossRef] [PubMed]

64. Madhu, G.; Bose, V.C.; Aiswaryaraj, A.; Maniammal, K.; Biju, V. Defect dependent antioxidant activity of nanostructured nickel oxide synthesized through a novel chemical method. Colloids Surf. A Physicochem. Eng. Asp. 2013, 429, 44-50. [CrossRef]

65. Meng, J.; Fang, Y.; Zhang, A.; Chen, S.; Xu, T.; Ren, Z.; Han, G.; Liu, J.; Li, H.; Zhang, Z. Phenolic content and antioxidant capacity of Chinese raisins produced in Xinjiang Province. Food Res. Int. 2011, 44, 2830-2836. [CrossRef] 
66. Benzie, I.F.; Strain, J.J. The ferric reducing ability of plasma (FRAP) as a measure of "antioxidant power": The FRAP assay. Anal. Biochem. 1996, 239, 70-76. [CrossRef] [PubMed]

67. Najee, H.; Kamerzan, C.; Marutescu, L.; Gheorghe, I.; Popa, M.; Gradisteanu, G.; Lazar, V. Antifungal activity of some medicinal plant extracts against Candida albicans nosocomial isolates. Rom. Biotechnol. Lett. 2018, 23, 14073.

68. Muhsin, T.M.; Al-Zubaidy, S.R.; Ali, E.T. Effect of garlic bulb extract on the growth and enzymatic activities of rhizosphere and rhizoplane fungi. Mycopathologia 2001, 152, 143-146. [CrossRef]

69. Zajc, J.; Gostinčar, C.; Černoša, A.; Gunde-Cimerman, N. Stress-tolerant yeasts: Opportunistic pathogenicity versus biocontrol potential. Genes 2019, 10, 42. [CrossRef]

70. Borrego, S.; Molina, A.; Santana, A. Fungi in archive repositories environments and the deterioration of the graphics documents. EC Microbiol. 2017, 11, 205-226. 